\title{
Article \\ MicroRNA Alterations Induced in Human Skin by Diesel Fumes, Ozone, and UV Radiation
}

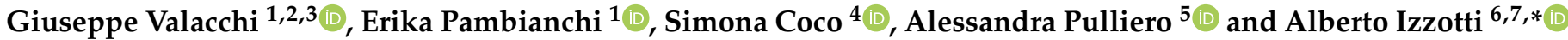 \\ 1 Animal Science Department, Plants for Human Health Institute, North Carolina State University, \\ Research Campus Kannapolis, Kannapolis, NC 28081, USA; gvalacc@ncsu.edu (G.V.); \\ epambia@ncsu.edu (E.P.) \\ 2 Department of Environmental Sciences and Prevention, University of Ferrara, 44121 Ferrara, Italy \\ Department of Food and Nutrition, Kyung Hee University, Seoul 130-701, Korea \\ 4 Lung Cancer Unit, IRCCS Ospedale Policlinico San Martino, 16132 Genova, Italy; simona.coco@hsanmartino.it \\ 5 Department of Health Sciences, University of Genova, 16132 Genova, Italy; alessandra.pulliero@unige.it \\ 6 Department of Experimental Medicine, University of Genova, 16132 Genova, Italy \\ 7 UOC Mutagenesis and Cancer Prevention, IRCCS San Martino Hospital, 16132 Genova, Italy \\ * Correspondence: izzotti@unige.it; Tel.: +39-010-3538522
}

Citation: Valacchi, G.; Pambianchi, E.; Coco, S.; Pulliero, A.; Izzotti, A. MicroRNA Alterations Induced in Human Skin by Diesel Fumes, Ozone, and UV Radiation. J. Pers. Med. 2022, 12, 176. https://doi.org/10.3390/ jpm12020176

Academic Editor: David

Alan Rizzieri

Received: 6 October 2021

Accepted: 24 January 2022

Published: 28 January 2022

Publisher's Note: MDPI stays neutral with regard to jurisdictional claims in published maps and institutional affiliations.

Copyright: (C) 2022 by the authors. Licensee MDPI, Basel, Switzerland. This article is an open access article distributed under the terms and conditions of the Creative Commons Attribution (CC BY) license (https:// creativecommons.org/licenses/by/ $4.0 /)$.

\begin{abstract}
Epigenetic alterations are a driving force of the carcinogenesis process. MicroRNAs play a role in silencing mutated oncogenes, thus defending the cell against the adverse consequences of genotoxic damages induced by environmental pollutants. These processes have been well investigated in lungs; however, although skin is directly exposed to a great variety of environmental pollutants, more research is needed to better understand the effect on cutaneous tissue. Therefore, we investigated microRNA alteration in human skin biopsies exposed to diesel fumes, ozone, and UV light for over $24 \mathrm{~h}$ of exposure. UV and ozone-induced microRNA alteration right after exposure, while the peak of their deregulations induced by diesel fumes was reached only at the end of the $24 \mathrm{~h}$. Diesel fumes mainly altered microRNAs involved in the carcinogenesis process, ozone in apoptosis, and UV in DNA repair. Accordingly, each tested pollutant induced a specific pattern of microRNA alteration in skin related to the intrinsic mechanisms activated by the specific pollutant. These alterations, over a short time basis, reflect adaptive events aimed at defending the tissue against damages. Conversely, whenever environmental exposure lasts for a long time, the irreversible alteration of the microRNA machinery results in epigenetic damage contributing to the pathogenesis of inflammation, dysplasia, and cancer induced by environmental pollutants.
\end{abstract}

Keywords: microRNAs; environmental risk factors; cutaneous tissues; ozone exposure

\section{Introduction}

The World Health Organization (WHO) estimated that circa 90\% of the global urban population lives with pollutant levels exceeding WHO guideline limits. This has been linked to the premature death of seven million people each year [1]. The target organs of pollution include the lungs, gut, brain, and mainly the skin [2].

The skin is the largest sensory organ (approximately $2 \mathrm{~m}^{2}$ ) in our body and is composed of two main layers: the epidermis and the dermis. The dermis is mainly formed of fibroblasts involved in the secretion of elastin and collagen fibers, embedded with nerve endings, sebaceous glands, hair follicles, and blood and lymphatic vessels. During the process of differentiation/keratinization, keratinocytes withdraw from the cell cycle and begin to express differentiation-dependent markers (i.e., keratins), eventually becoming anucleated densely keratinized corneocytes [3]. These cells are held together in the multilayered stratum corneum by a lipid-laden extracellular matrix (ECM), which performs the barrier function of the skin [4]. Recently, it has been demonstrated that the skin is not an impenetrable tissue, and it can even be a gateway for certain pollutants, even affecting internal organs [5]. 
The use of the word "pollution" can be misleading given that there are several different pollutants that can affect our health. Based on their chemical and physical properties as well as their sources, The United States Environmental Protection Agency (EPA) has identified the most common air pollutants, also known as "criteria air pollutants", as ozone $\left(\mathrm{O}_{3}\right)$, particulate matter $(\mathrm{PM})$, carbon monoxide $(\mathrm{CO})$, lead, sulfur dioxide $\left(\mathrm{SO}_{2}\right)$, and nitrogen dioxide $\left(\mathrm{NO}_{2}\right)$ [6]. Clear evidence of the correlation between each pollutant and skin disorder has not yet been established; however, the harmful effects of $\mathrm{O}_{3}, \mathrm{PM}$, and UV radiation have been well demonstrated. To date, only a few studies have compared the cutaneous effect of different pollutant exposure. Several skin diseases such as atopic dermatitis (AD), psoriasis, acne, and, in some cases, also skin cancer have been linked, either directly or indirectly, to pollution exposure, although the debate is still open. In particular, exposure to $\mathrm{O}_{3}$ and $\mathrm{PM}$ have been demonstrated to be associated with skin aging, including wrinkle formation and dark spots, respectively [7]. In addition, the study by $\mathrm{Xu}$ et al. [8] demonstrated the association between ozone exposure and cutaneous conditions by analyzing the emergency room (ER) visits for skin conditions together with the levels of several air pollutants such as $\mathrm{O}_{3}, \mathrm{PM}_{10}, \mathrm{SO}_{2}$, and $\mathrm{NO}_{2}$. The authors were able to extrapolate that skin conditions such as urticaria, eczema, contact dermatitis, rash/other non-specific eruptions, and infected skin diseases were exacerbated by exposure to increased ozone levels. Another more recent publication has further examined the association of short-term changes in air quality with emergency department (ED) visits for urticaria in Canada. A total of 2905 ED visits were analyzed, and a positive and significant correlation was observed between air quality levels and ED visits for urticaria, confirming that air pollution can affect skin physiology $[9,10]$.

$\mathrm{O}_{3}$ and PM have quite different mechanisms of action, while $\mathrm{O}_{3}$ is not able to penetrate the skin and reacts directly with the lipids present in the stratum corneum, PM can possibly enter the skin via the hair follicles or enable the skin to absorb components present in the PM (such as polycyclic aromatic hydrocarbons-PAH) and lead to an epidermal OxInflammatory reaction [11,12].

Indeed, it is now well established that ozone and diesel particles, together with UV radiation, can induce a proinflammatory response in parallel to an altered tissue redox homeostasis [13].

In addition to the ability of pollution to produce oxidative and inflammatory mediators, recent studies have indicated that DNA methylation patterns can be greatly influenced by environmental factors such as ambient air pollution, and these epigenetic changes are linked with diverse diseases [14-16].

In fact, several reports have shown that epigenetic alterations could be an important pathway through which environmental factors exert their effects [14,17]. Epigenetic refers to the alterations in gene expression levels that occur without changes in the underlying DNA sequence (such as DNA methylation, histone modification, miRNA, and noncoding RNA expression $[18,19])$. It should be mentioned that several pathologies, including cancers, have been associated with epigenetic modifications [18]. Exposure to environmental stimuli may result in epigenetic changes, which can impact gene expression and predisposition to developing pathological conditions. [20]. Understanding epigenetic alterations due to exposure to specific pollutants may lead to the development of biomarkers to assess the disease risk associated with air pollution. Micro-RNAs and noncoding RNAs (ncRNAs) play critical roles in gene expression and contribute to epigenetic control in the process [21]. For this reason, the present study aimed to evaluate the different miRNA epigenetic patterns related to the specific exposure of cutaneous tissues to pollutants such as ozone, diesel exhaust, and to the stressor UV radiation, which is the most toxic and most present in urban areas. 


\section{Materials and Methods}

\subsection{Ex Vivo Human Skin Explants Preparation}

Human skin biopsies (12 $\mathrm{mm}$ diameter) were obtained from three healthy Caucasian donors (40-45 years old) who underwent elective abdominoplasties at Hunstad/Kortesis/ Bharti Cosmetic Surgery clinic. In total, 24 punch biopsies were taken from the abdominal skin of each donor, and subcutaneous fat was removed with sterile scissors and a scalpel.

The biopsies, comprising dermal and epidermal layers, were rapidly rinsed with Phosphate-Buffered Saline (PBS, Gibco, New York, NY, USA). The biopsies were then moved into 6-well dishes containing $2 \mathrm{~mL}$ of complete Dulbecco's Modified Eagle Medium (DMEM) with 10\% Fetal Bovine Serum (FBS) and 1\% of antibiotics and antimycotics (100 U/mL penicillin and $100 \mu \mathrm{g} / \mathrm{mL}$, Gibco, New York, NY, USA) added; then, they were incubated at $37^{\circ} \mathrm{C}$ in $5 \% \mathrm{CO}_{2}$ for overnight recovery.

The following day the medium was replaced with a fresh one, and the biopsies were exposed to the different pollutants as discussed below.

The experiment was performed at least in triplicate for each condition and donor.

\subsection{Ex Vivo Human Skin Explants Ozone $\left(\mathrm{O}_{3}\right)$ Exposure}

A full $24 \mathrm{~h}$ after skin biopsy collection, ex vivo explants were allocated into a plexiglass sealed chamber, connected to the ozone generator machine (ECO3 model CUV-01, Model 306 Ozone Calibration Source, 2B Technologies, Ozone solution, ITA), and exposed to $0.2 \mathrm{ppm}$ for $4 \mathrm{~h}$. Sample biopsies were then collected following ozone exposure (T0) or after $24 \mathrm{~h}$ (T24).

\subsection{Ex Vivo Human Skin Explants Diesel Engine Exhaust (Diesel) Exposure}

Another set of skin biopsies was exposed to diesel engine exhaust by letting the engine run for $10 \mathrm{~s}$ and allowing the exhaust to reach the sealed exposure chamber where the skin biopsies remained for $30 \mathrm{~min}$. Specifically, the skin explants were placed into a sealed plexiglass box connected to a Kubota RTV-X900 diesel engine (3-cylinder, 4-cycle diesel with overhead valves, $1123 \mathrm{cc}$ with $24.8 \mathrm{HP}$ at $3000 \mathrm{rpm}$ ). After the $30 \mathrm{~min}$ of Diesel exposure, the exposure medium was changed with a fresh one, and the biopsies were either collected (T0) or moved back into the incubator at $37^{\circ} \mathrm{C}$ in $5 \% \mathrm{CO}_{2}$ for $24 \mathrm{~h}$ (T24).

\subsection{Ex Vivo Human Skin Explants Ultraviolet Light (UV) Exposure}

The other human skin biopsies were exposed to 200 milli Joule (mJ) UVA/UVB light, which equates to circa $2 \mathrm{~h}$ at solar apex and corresponding to 10 minimal erythemal doses $\left(\mathrm{MED}, 1 \mathrm{MED}=20 \mathrm{~mJ} / \mathrm{cm}^{2}\right.$ ) [22]. UVA/UVB light (exposure of circa $20 \mathrm{~s}$ ) was generated by a Sol1A Class ABB Solar Simulator, equipped with a xenon lamp (Newport Oriel Sol1A, CA, USA). Samples were collected after UV exposure (T0), or after $24 \mathrm{~h}$ (T24).

To match the real solar spectrum at the condition of the sun at the Zenith angle of 0, we performed UV exposure with a UVA/UVB ratio of 21:1 measured with a radiometer ILT2400 Hang-Held Light Meter/Optometer (International Light Technologies, Inc., Peabody, MA, USA).

\subsection{Total RNA Extraction and Lyophilization}

Total RNA extraction was performed using a miRNeasy Mini kit QIAGEN (Hilgen, DE, cat. 1038703) and Qiazol Lysis Reagent 50 QIAGEN (Hilgen, DE, cat. 1023537), according to the manufacturer's protocol. Briefly, skin biopsies were homogenized in $700 \mu \mathrm{L}$ of Qiazol Lysis Reagent, with a tissue homogenizer (Precellys 24 homogenizer, 5 cycles $6500 \mathrm{rpm} 3 \times 30 \mathrm{~s}$, at $\left.4^{\circ} \mathrm{C}\right)$. Samples were then centrifuged $(12,700 \mathrm{rpm}, 5 \mathrm{~min}$ at $4{ }^{\circ} \mathrm{C}$ ), the supernatant was collected and transferred to a new tube containing $140 \mu \mathrm{L}$ of Chloroform, and then centrifuged again $\left(12,000 \mathrm{~g}, 15 \mathrm{~min}\right.$ at $\left.4{ }^{\circ} \mathrm{C}\right)$. The upper aqueous phase was transferred to a new tube containing 1.5 volumes of ethanol $100 \%$ and mixed thoroughly. Then, half of the volume was moved into the RNeasy Mini spin column and centrifuged $(8000 \times g, 30 \mathrm{~s}, \mathrm{RT})$. This last step was repeated for the other half of the volume. 
Next, $700 \mu \mathrm{L}$ of diluter Buffer RWT was added to the column, centrifuged $(8000 \times g, 30 \mathrm{~s}$, RT), and then the liquid was discarded. Next, the addition of $500 \mu \mathrm{L}$ of diluted Buffer RPE to the column, centrifugation $(8000 \times g, 30 \mathrm{~s}, \mathrm{RT})$, and discarding of the liquid was repeated twice. Finally, the columns were moved into new Rnase free tubes, centrifuged at maximum speed for $1 \mathrm{~min}$, and $30 \mu \mathrm{L}$ of RNase free water was added to the spin column membrane. Elution of RNA was performed by centrifugation at $8000 \mathrm{~g}, 1 \mathrm{~min}, \mathrm{RT}$.

Then, the eluted RNA was concentrated via a lyophilization process $(1.5 \mathrm{~h}$, Low Setting, RT) using a Savant DNA SpeedVac Concentrator (Savant DNA120, DNA 120 OP, Thermo Electron Corporation, Waltham, MA, USA).

\section{6. miRNA-Microarray and Bioinformatic Analyses}

miRNA expression profiling was carried out by an Agilent platform, following the miRNA Microarray protocol v.3.1.1 (Agilent Technologies, Santa Clara, CA, USA). Briefly, $50 \mathrm{ng}$ of total RNA containing miRNAs and Spike-in controls underwent dephosphorylation and a labeling step with Cyanine 3-pCp. The Cy3-labeled RNA was then purified using Micro Bio-Spin P-6 Gel Column (Bio-Rad Laboratories, Inc., Hercules, CA, USA) and hybridized on a Human miRNA microarray slide $8 \times 60 \mathrm{~K}$ (Agilent Technologies; including 2549 miRNAs, miRBase 21.0 ) at $55^{\circ} \mathrm{C}$ for $20 \mathrm{~h}$. After washing, the slides were scanned by a G2565CA scanner (Agilent Technologies), and the images were extracted by Feature Extraction software v.10 (Agilent Technologies). Microarray raw data were deposited in the Gene Expression Omnibus (http:/ / www.ncbi.nlm.nih.gov/geo); GEO number accession requested, 15 March 2022).

Bioinformatic analyses were performed using the GeneSpring software (GeneSpring Multi-Omic Analysis v 14.9 by Agilent Technologies). For each sample, the intensities of replicated spots on each array were log transformed and averaged. Data processing was performed by 3D principal component analysis (PCA) scores and Hierarchical Clustering.

Comparisons between sets of data were performed by evaluating the fold changes. A volcano Plot T-Test analysis for all miRNA entities was run, using Fold Change $\geq 2$ and $p$-value $\leq 0.05$. Because log transformed data were used, negative and zero signals were transformed into 0.01 values. This approach could result in artificially high-fold variations. To correct this artifact, we now report in Tables that fold variation values upregulated more than 10 times into '>10-fold' and fold variation values downregulated more than 10 times into $<0.1$-fold.

miRNAs related to three different environmental exposures (Environmental Exposure miRNA Signature) were determined by analyzing miRNAs comparatively in exposed vs. non-exposed subjects. Environmental exposures were determined for each sample according to (a) Diesel, (b) Ozone, and (c) UV.

To understand the relationship between environmental exposure signatures and their biological significance in human tissues, a target detection for each environmental exposure signature was performed using the TargetScan prediction database.

\section{Results}

\section{Comparison of miRNA Expression Profile between Pollutants}

The overall trend of miRNA expression in human skin either untreated or exposed to diesel, ozone, and UV was evaluated at 0 and $24 \mathrm{~h}$ by Line plot analysis. (Figure 1 ).

The expression line plot was similar at 0 and $24 \mathrm{~h}$ in unexposed skin. Diesel induced dramatic alteration of miRNA profile compared to air but mainly after $24 \mathrm{~h}$. Conversely, miRNA alteration induced by ozone was remarkable at time 0 while being much more attenuated compared to untreated skin at $24 \mathrm{~h}$. miRNA profiles were slightly increased by UV exposure, mostly at $24 \mathrm{~h}$ compared to unexposed skin.

Scatter plot analyses were performed to assess the number of miRNAs with more than two-fold profile alteration compared to untreated (air-exposed), Figure 2. 


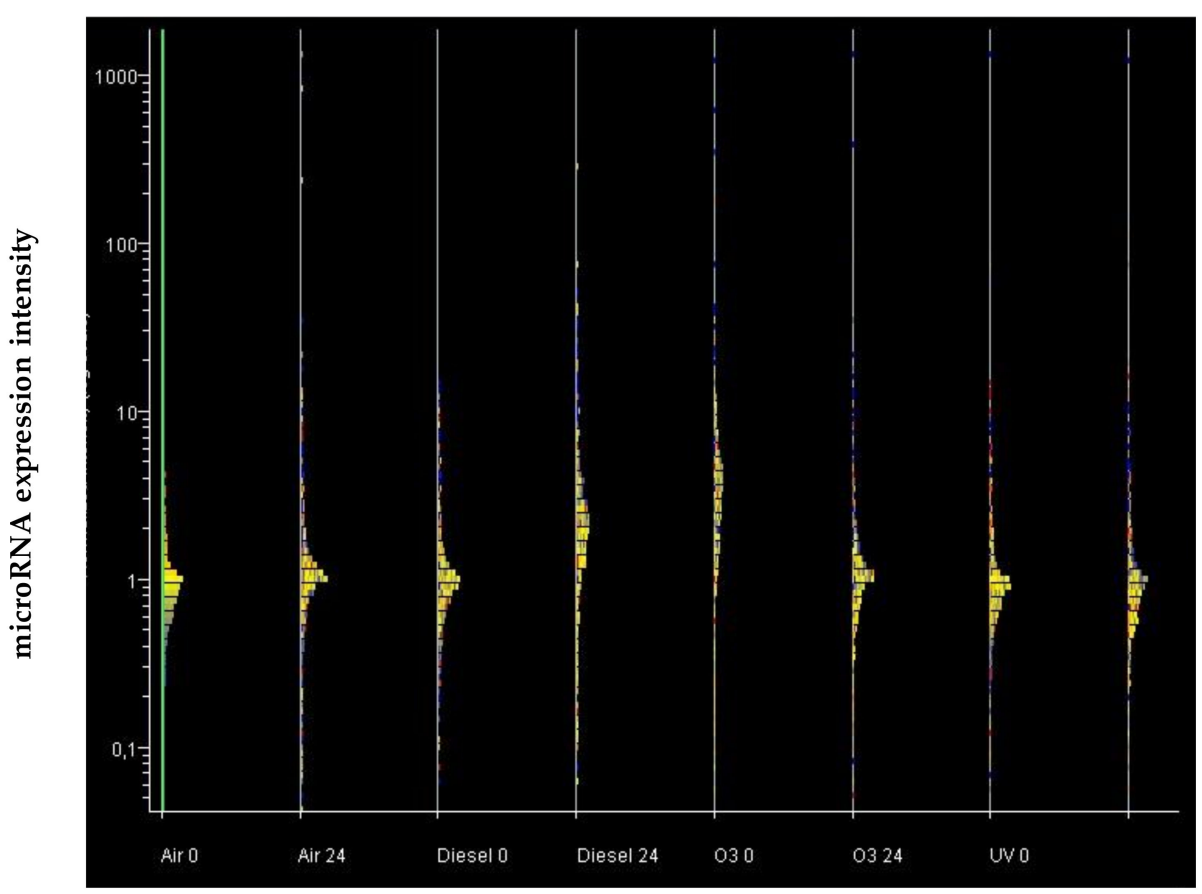

Pollutans exposures

Figure 1. Line plot analysis of the overall expression of the 2549 human miRNAs analyzed under each experimental condition tested. The expression of 2549 human miRNAs was evaluated at 0 and $24 \mathrm{~h}$ in skin either unexposed (Air) or exposed to diesel, ozone, and UV. miRNAs are distributed in horizontal lines according to their level of expression, the majority being located at intermediate levels of expression (central part of the distribution), and the minority being located at high and low levels of expression (lower and upper part of the distribution). The distribution profile is progressively modified according to the treatment used.

Each miRNA is represented by colored dots, whose expression intensity can be inferred from the position on the horizontal and vertical axes. The horizontal axis indicates the miRNA expression level in untreated samples and the vertical axis in treated (diesel, ozone, and UV) samples. The central diagonal lines indicate the equivalence ( $<$ two-fold variation) in the intensity of miRNA expression in treated as compared to untreated samples. miRNA dots falling outside the green diagonal lines indicate higher than two-fold differences in miRNA expression between the tested experimental conditions. Scatter plot analyses compared untreated (air) and treated (diesel, ozone, and UV) samples both at 0 and $24 \mathrm{~h}$. miRNA colors reflect the signal intensity in the treated samples (red is high, yellow is intermediate, and blue is low). Upregulated miRNAs are located in the upper-right area, and downregulated miRNAs are in the lower-right area of the scatter plots.

For diesel and to a lesser extent for UV, a cloud of downregulated miRNAs was detected already at $0 \mathrm{~h}$, while the additional cloud of upregulated miRNAs was detected only at $24 \mathrm{~h}$.

Conversely, for ozone, two clouds of both upregulated and downregulated miRNAs were already detected at time 0 .

At time 0 , out of the 2549 miRNAs tested, $100(2.5 \%)$ were downregulated (blue dots) while $122(4.8 \%)$ were upregulated (red dots) after exposure to diesel. Immediately after ozone exposure, we evidenced 262 (10.3\%) downregulated miRNAs and $297(11.6 \%)$ upregulated; however, upon UV exposure, we detected that 238 (9.3\%) were downregulated and $294(11.5 \%)$ upregulated. 
Time 0
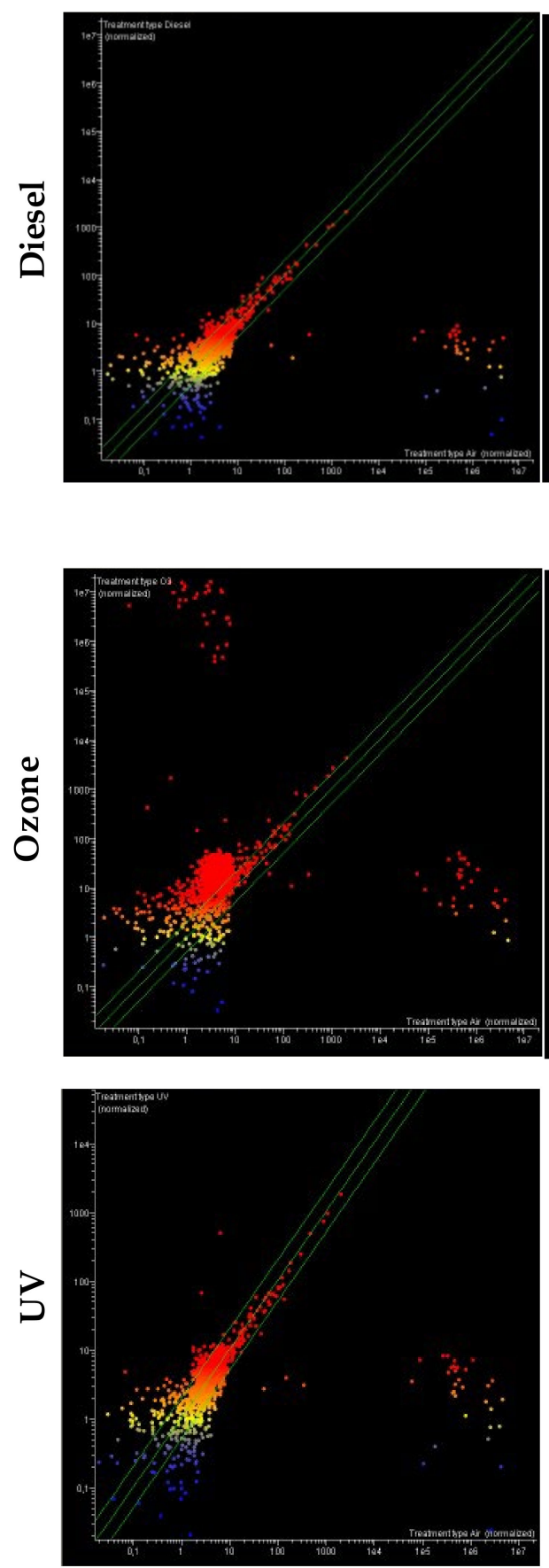

Time $24 \mathrm{~h}$
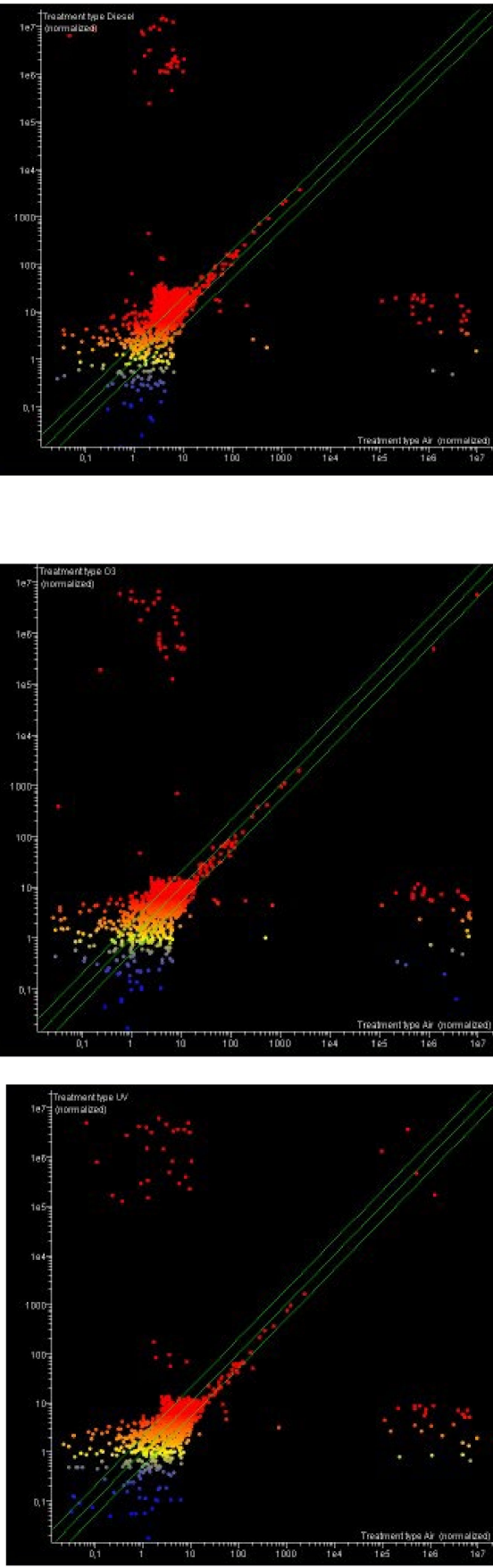

Figure 2. Scatter plot analysis of changes in miRNA-expression in human skin upon exposure to diesel, ozone, and UV at different times ( 0 and $24 \mathrm{~h})$.

At $24 \mathrm{~h}$, out of the 2549 miRNAs tested, 219 (8.6\%) were downregulated (blue dots), and 251 (9.8\%) were upregulated (red dots) after exposure to diesel; $229(8.9 \%)$ were downregulated, and $238(9.3 \%)$ upregulated after ozone exposure; and $174(6.8 \%)$ were downregulated and 241 (9.4\%) upregulated after UV exposure.

The effects of the tested pollutants on the whole miRNA expression profile were compared by unsupervised principal component analysis of variance (PCA) and supervised hierarchical cluster (HCA) analyses.

The PCA at $0 \mathrm{~h}$ (Figure 3) showed that the miRNA profiles of ozone and UV treated samples were remarkably altered, being located far away and in another quadrant, as com- 
pared to the untreated (air) samples. Conversely, the miRNA profile in diesel-treated samples was only slightly distant from the untreated samples, being located in the same quadrant.

Time 0

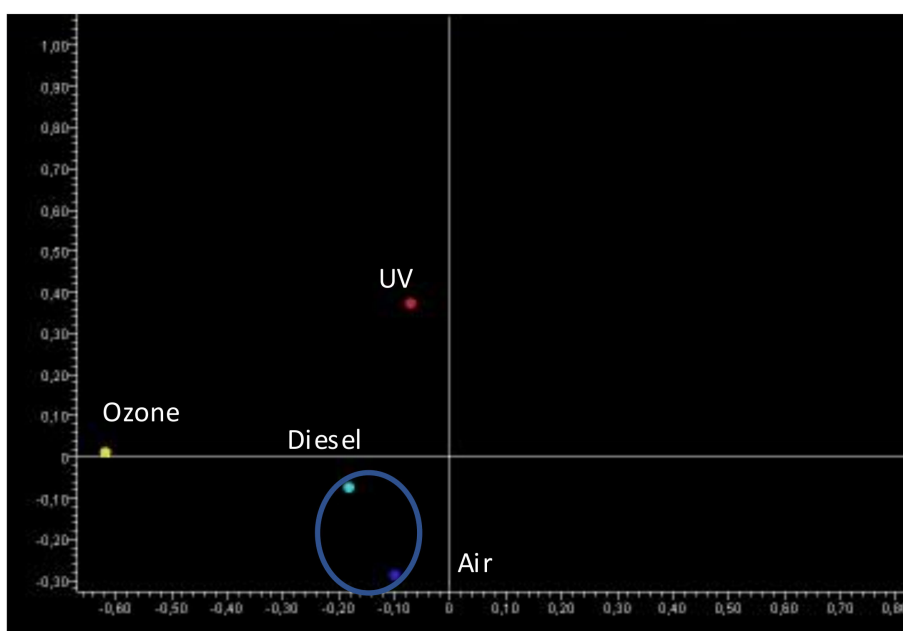

Time $24 \mathrm{~h}$

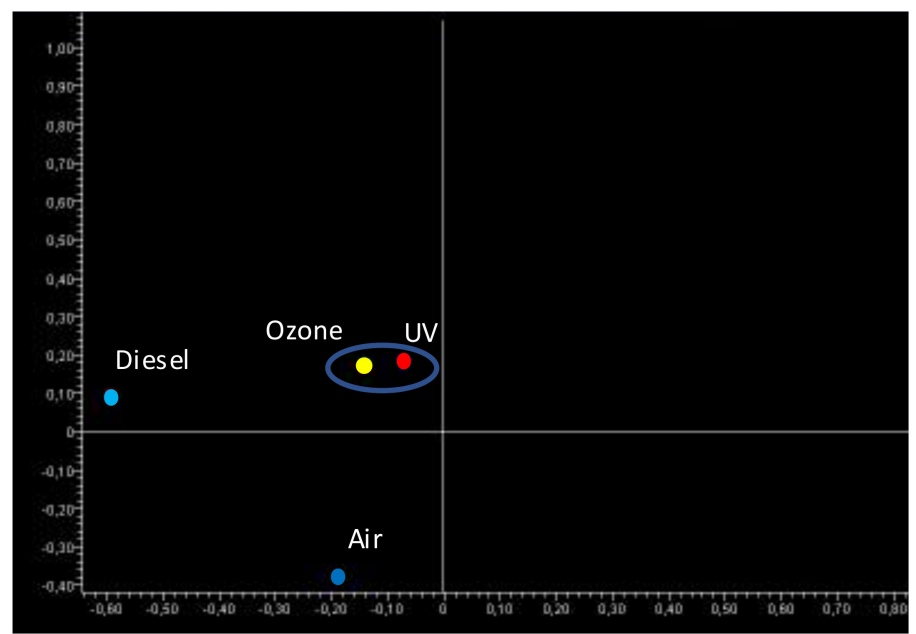

Figure 3. Bidimensional principal component analysis (PCA) of miRNA profiles of skin samples either untreated (air) or treated with diesel, ozone, and UV at 0 (left panel) and $24 \mathrm{~h}$ (right panel). PCA1 ( $\mathrm{X}$ axis), PCA2 (Y axis).

The PCA at $24 \mathrm{~h}$ (Figure 3) reported that the miRNA profiles of all pollutant-treated samples (including diesel) were located far away and in another quadrant compared to the untreated sample. The samples treated with diesel and ozone were close to each other but far away from the UV-treated sample. This finding indicates that the pattern of miRNAs altered by UV is quite different from those induced by ozone and diesel exposure. This situation is likely due to the different pathogenic mechanisms induced by exciting radiation (UV) as compared to gaseous (ozone) and mixed gaseous-particulate pollutants (diesel).

The HCA at $0 \mathrm{~h}$ (Figure 4 ) showed that the most remarkable alterations in miRNA profiles were induced by ozone, whose expression profile was located at the right of the hierarchical tree far away from the untreated (air) sample. An intermediate situation occurred for UV, whose alteration profile was in the central part of the hierarchical tree. miRNA alterations induced by diesel were less remarkable; indeed, the profile was linked to the untreated (air) sample in the hierarchical tree.

The HCA at $24 \mathrm{~h}$ (Figure 4) indicated that the most remarkable alterations in miRNA profiles were induced by diesel, whose expression profile was located at the right of the hierarchical tree far away from the untreated (air) sample. An intermediate response was visible for UV, whose alteration profile was located in the central part of the hierarchical tree. On the other hand, the changes in miRNA profiles induced by ozone exposure were less remarkable; in fact, this profile was linked to the untreated (air) sample in the hierarchical tree.

A Venn diagram data representation was used to identify microRNAs presented in both lists, i.e., altered by each pollutant both at 0 and $24 \mathrm{~h}$.

These miRNAs represent the specific miRNA signature induced by each pollutant. Their identity is reported in Table 1 (diesel), Table 2 (ozone), and Table 3 (UV). These Tables enlist miRNAs modulating their expression more than two-fold and above the statistical significance threshold of $p<0.05$ considering the four replicates spotted in each microarray. A comparison of fold variation was made by dividing the signal intensity detected in treated skin by those detected in untreated skin. Fold variation values $>2.0$ indicate upregulation after treatment and $<0.5$ downregulation after treatment. Available information for the 
main biological pathways regulated by modulated microRNAs is also reported (column Function), as well as the reference from where this information was collected.

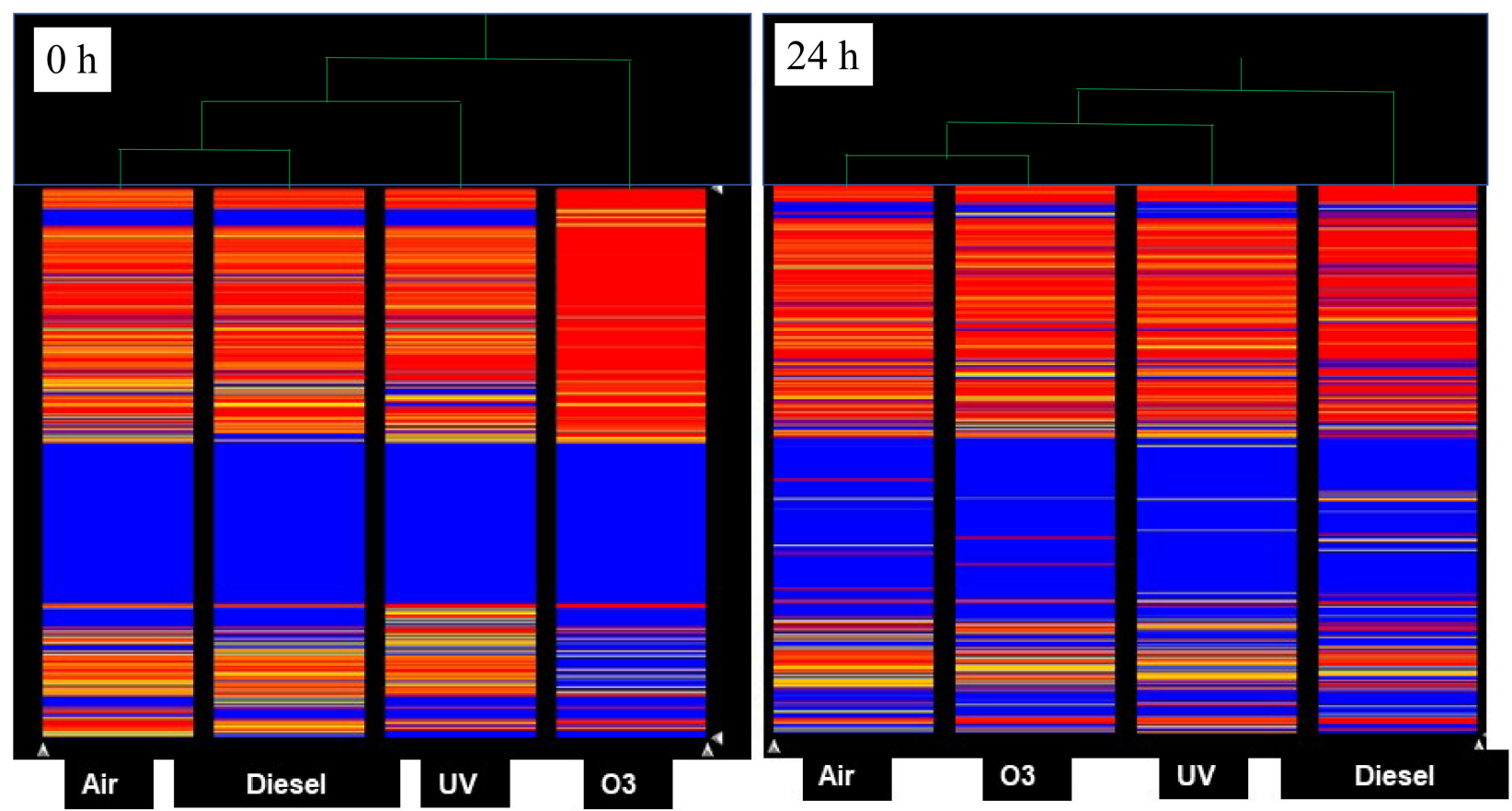

Figure 4. Hierarchical Cluster Analysis (HCA) reporting the expression of the 2549 miRNAs (colored horizontal bars) tested at time 0 (left panel) and $24 \mathrm{~h}$ (right panel) in samples either untreated (air) or treated with pollutants (ozone, diesel, and UV). Columns report miRNA expression profiles for each experimental condition. Similar expression profiles are linked in the upper hierarchical tree (green), thus being located nearby, while different expression profiles are located far away in the hierarchical tree.

Table 1. Diesel.

\begin{tabular}{cccc}
\hline MicroRNA & Fold Change & Function & Reference \\
\hline hsa-miR-495-5p & $>10$ & Promotes Th2 differentiation in allergic rhinitis, as a tumor suppressor & [23] \\
\hline hsa-miR-628-5p & $>10$ & Inhibits osteoblast differentiation via RUNX2 & [24] \\
\hline hsa-miR-361-3p & $>10$ & $\begin{array}{c}\text { Suppresses proliferation, invasion inhibited cells invasive and proliferative } \\
\text { abilities, and cell lines invasion and proliferation }\end{array}$ & [25,26] \\
\hline hsa-miR-875-5p & $>10$ & Promotes cellular apoptosis and proliferation & Tumor suppressor \\
\hline hsa-miR-509-3p & $>10$ & Suppresses cell proliferation, invasiveness, and migration in colorectal cancer & [30,31] \\
\hline hsa-miR-518b & $>10$ & Cell proliferation, inducing G1 cell cycle arrest and apoptosis & [32] \\
\hline hsa-miR-516b-5p & $>10$ & Induces apoptosis & [33] \\
\hline hsa-miR-381-5p & $>10$ & Promotes proliferation, migration, and metastasis of NSCLC & [35] \\
\hline hsa-miR-661 & $>10$ & Antitumor functions & [36] \\
\hline hsa-miR-216a-3p & $>10$ & Inflammatory responses and potential estrogen receptor sensitivity & [38] \\
\hline hsa-miR-548c-3p & $>10$ & Cell proliferation and autophagy & \\
\hline hsa-miR-106a-3p & $>10$ & Promotes angiogenesis and modulates cell proliferation &
\end{tabular}


Table 1. Cont.

\begin{tabular}{|c|c|c|c|}
\hline MicroRNA & Fold Change & Function & Reference \\
\hline hsa-miR-671-3p & $>10$ & $\begin{array}{l}\text { Suppresses proliferation and invasion of breast cancer cells and regulates } \\
\text { metabolic processes }\end{array}$ & {$[39,40]$} \\
\hline hsa-miR-544a & $>10$ & Regulates migration and invasion in colorectal cancer cells & [41] \\
\hline hsa-miR-614 & $>10$ & Inflammatory process & [42] \\
\hline hsa-miR-525-3p & $<10$ & Modifies the expression of proinflammatory cytokines; apoptosis & [43] \\
\hline hsa-miR-378c & $<10$ & Regulates the angiogenic capacity of CD34(+) progenitor cells & [44] \\
\hline hsa-miR-924 & $<10$ & Suppresses the proliferation, migration, and invasion of NSCLC cells & [45] \\
\hline hsa-miR-522-3p & $<10$ & $\begin{array}{l}\text { Cell proliferation of human glioblastoma cells; modulates the expression of } \\
\text { proinflammatory cytokines }\end{array}$ & [46] \\
\hline hsa-miR-431-5p & $<10$ & Promotes differentiation and regeneration of cells & {$[47,48]$} \\
\hline hsa-miR-770-5p & $<10$ & Suppresses cell apoptosis and the release of proinflammatory factors & [49] \\
\hline hsa-miR-183-5p & $<10$ & $\begin{array}{l}\text { Tumor suppressor inflammation and alters miRNA expression in the } \\
\text { airway epithelium }\end{array}$ & [50] \\
\hline hsa-miR-598-5p & $<10$ & $\begin{array}{l}\text { Promotes cell proliferation and cell cycle progression in human colorectal } \\
\text { carcinoma; elevates apoptosis }\end{array}$ & [51] \\
\hline hsa-miR-486-5p & $<10$ & $\begin{array}{l}\text { Regulation of heart contraction, muscle contraction, and ion } \\
\text { channel activity }\end{array}$ & [52] \\
\hline hsa-miR-125a-5p & $<10$ & $\begin{array}{l}\text { Regulates stress response, apoptosis, proliferation, angiogenesis, and } \\
\text { expression of genes, associated with human lung cancer }\end{array}$ & [53] \\
\hline hsa-miR-34b-5p & $<10$ & $\begin{array}{l}\text { Regulates stress response, apoptosis, proliferation, angiogenesis, and } \\
\text { expression of genes, and is upregulated during cardiac hypertrophy }\end{array}$ & [54] \\
\hline hsa-miR-301a-3p & $<10$ & Promotes autophagy and inhibits apoptosis & {$[55,56]$} \\
\hline hsa-miR-23c & $<10$ & $\begin{array}{l}\text { Inhibits cell proliferation and induces apoptosis of hepatocellular } \\
\text { carcinoma cells; cell growth arrest and apoptosis. }\end{array}$ & [57] \\
\hline hsa-miR-383-5p & $<10$ & Oxidative stress and inflammation-related factors & [58] \\
\hline hsa-miR-574-5p & $<10$ & Promotes the differentiation of human cardiac fibroblasts & [59] \\
\hline hsa-miR-151a-5p & $<10$ & $\begin{array}{l}\text { Regulation of cellular respiration and ATP production through } \\
\text { targeting Cytb }\end{array}$ & [60] \\
\hline hsa-miR-514a-3p & $<10$ & Attenuates proliferation and increases chemoresistance & {$[61]$} \\
\hline hsa-miR-136-3p & $<10$ & Promotes apoptosis in gastric cancer cells & [62] \\
\hline hsa-miR-1-3p & $<10$ & Inflammation; regulator of heart adaption after ischemia or ischemic stress & [63] \\
\hline hsa-miR-18a-3p & $<10$ & Downregulated in aging cells; induces the apoptosis of colon cancer cells & {$[64]$} \\
\hline hsa-miR-502-5p & $<10$ & Enhances early apoptosis and inhibits proliferation of breast cancer cells & {$[65]$} \\
\hline hsa-miR-451a & $<10$ & Apoptosis; inhibits autophagy & [66] \\
\hline hsa-miR-19b-1-5p & $<10$ & Linked to oxidative stress, inflammation, and atherosclerosis & {$[67]$} \\
\hline hsa-miR-873-5p & $<0.1$ & $\begin{array}{l}\text { Tumor suppressor in thyroid cancer by inhibiting the proliferation, } \\
\text { migration, and invasion of the cancer cells }\end{array}$ & [68] \\
\hline hsa-miR-212-5p & $<0.1$ & $\begin{array}{l}\text { Promotes cancer cell apoptosis and suppresses cancer cell proliferation } \\
\text { and invasion }\end{array}$ & [69] \\
\hline hsa-miR-552-5p & $<0.1$ & Tumorigenesis; progression & [70] \\
\hline hsa-let-7a-3p & $<0.1$ & Linked to oxidative stress, inflammation, and atherosclerosis & [71] \\
\hline hsa-miR-495-3p & $<0.1$ & $\begin{array}{c}\text { Regulates proliferation, apoptosis, migration, and invasion in metastatic } \\
\text { prostate cancer cells. }\end{array}$ & [68] \\
\hline
\end{tabular}


Table 1. Cont.

\begin{tabular}{|c|c|c|c|}
\hline MicroRNA & Fold Change & Function & Reference \\
\hline hsa-miR-767-3p & $<0.1$ & Promoted cell proliferation in human melanoma cell lines & [72] \\
\hline hsa-miR-27b-5p & $<0.1$ & Involved in beige and brown adipogenesis after cold exposure & [73] \\
\hline hsa-miR-26a-2-3p & $<0.1$ & $\begin{array}{l}\text { Regulated stress response, apoptosis, proliferation, angiogenesis, and } \\
\text { expression of genes }\end{array}$ & [74] \\
\hline hsa-miR-629-5p & $<0.1$ & Action on tumor growth and metastasis in hepatocellular carcinoma & [75] \\
\hline hsa-miR-543 & $<0.1$ & Cell oxidative phosphorylation & [76] \\
\hline hsa-miR-515-5p & $<0.1$ & Upregulated in placentas from women with preeclampsia & [77] \\
\hline hsa-miR-708-5p & $<0.1$ & Induces apoptosis and suppresses tumorigenicity in renal cancer cells & [78] \\
\hline hsa-miR-378j & $<0.1$ & Tumor suppressor & [79] \\
\hline hsa-miR-548az-3p & $<0.1$ & Alters inflammation & [80] \\
\hline hsa-miR-876-5p & $<0.1$ & $\begin{array}{l}\text { Regulates regulation proliferation, migration, invasion, and glutaminolysis } \\
\text { in gastric cancer cells }\end{array}$ & [37] \\
\hline hsa-miR-656-3p & $<0.1$ & $\begin{array}{l}\text { Suppresses glioma cell proliferation, neurosphere formation, migration, } \\
\text { and invasion }\end{array}$ & [81] \\
\hline hsa-miR-944 & $<0.1$ & Increases p53 expression in cancer cells & [82] \\
\hline hsa-miR-518e-3p & $<0.1$ & Tumor suppressor & [83] \\
\hline hsa-miR-373-3p & $<0.1$ & $\begin{array}{l}\text { Promotes the invasion and migration of breast cancer; regulates } \\
\text { inflammatory cytokine-mediated chondrocyte proliferation }\end{array}$ & [32] \\
\hline
\end{tabular}

Table 2. Ozone exposure.

\begin{tabular}{|c|c|c|c|}
\hline MicroRNA & Fold Change & Function & Reference \\
\hline hsa-miR-628-5p & $>10$ & Inhibits osteoblast differentiation & [84] \\
\hline hsa-miR-15a-3p & $>10$ & Proliferation; inflammation; apoptosis & {$[25,26]$} \\
\hline hsa-miR-548am-3p & $>10$ & Induces proliferation and migration & {$[85]$} \\
\hline hsa-miR-550b-2-5p & $>10$ & Cancer promotion & {$[86]$} \\
\hline hsa-miR-495-5p & $>10$ & $\begin{array}{l}\text { Tumor suppressor; proliferation and differentiation of osteoblasts in mice; } \\
\text { inhibits the growth of fibroblasts in hypertrophic scar }\end{array}$ & [87] \\
\hline hsa-miR-345-3p & $>10$ & Apoptosis and inflammation & {$[24,88]$} \\
\hline hsa-miR-548q & $>10$ & Induces proliferation and migration & [89] \\
\hline hsa-miR-887-3p & $>10$ & Pathways in cancer & [86] \\
\hline hsa-miR-877-5p & $>10$ & Pathways in cancer & [90] \\
\hline hsa-miR-513c-5p & $>10$ & Pathways in cancer & {$[91]$} \\
\hline hsa-miR-422a & $>10$ & Pathways in cancer & [92] \\
\hline hsa-miR-194-5p & $>10$ & Pathways in cancer & [93] \\
\hline hsa-miR-378b & $>10$ & Inflammation and cell cycle & {$[94]$} \\
\hline hsa-miR-610 & $>10$ & Pathways in cancer & [95] \\
\hline hsa-miR-519e-5p & $>10$ & Atherosclerosis and pathways in cancer & [96] \\
\hline hsa-miR-627-5p & $>10$ & Cell proliferation and cancer promotion & {$[97,98]$} \\
\hline hsa-miR-548au-5p & $>10$ & Pathways in cancer & [99] \\
\hline
\end{tabular}


Table 2. Cont.

\begin{tabular}{|c|c|c|c|}
\hline MicroRNA & Fold Change & Function & Reference \\
\hline hsa-miR-770-5p & $>10$ & Apoptosis and inflammation & [100] \\
\hline hsa-miR-196b-3p & $>10$ & Cell proliferation & [101] \\
\hline hsa-miR-330-3p & $>10$ & Apoptosis and cell proliferation & [102] \\
\hline hsa-miR-617 & $>10$ & Pathways in cancer & [103] \\
\hline hsa-miR-375 & $>10$ & Cell proliferation and pathways in cancer & [104] \\
\hline hsa-miR-936 & $>10$ & Cell proliferation, pathways in cancer, and apoptosis & [105] \\
\hline hsa-miR-657 & $>10$ & Inflammation & [106] \\
\hline hsa-miR-542-5p & $>10$ & Mitochondrial dysfunction and inflammation & [107] \\
\hline hsa-miR-136-3p & $>10$ & Vascularization and pathways in cancer & [108] \\
\hline hsa-miR-409-5p & $>10$ & Cardiovascular process, proliferation, migration, and cell cycle. & {$[109,110]$} \\
\hline hsa-miR-154-3p & $>10$ & Pathways in cancer & {$[111,112]$} \\
\hline hsa-miR-378c & $>10$ & Proliferation and inhibited apoptosis & [113] \\
\hline hsa-miR-93-3p & $>10$ & Inflammation and apoptosis & [114] \\
\hline hsa-miR-556-3p & $>10$ & Cell proliferation and apoptosis & [115] \\
\hline hsa-miR-518c-5p & $>10$ & Tumor suppressor & {$[116]$} \\
\hline hsa-miR-23b-5p & $>10$ & Cell proliferation and cancer & [32] \\
\hline hsa-miR-504-5p & $>10$ & Cell proliferation and differentiation & [117] \\
\hline hsa-miR-509-3p & $>10$ & Cardiovascular process & [118] \\
\hline hsa-miR-514a-3p & $>10$ & Tumor suppressor & [119] \\
\hline hsa-miR-431-5p & $>10$ & Cell proliferation and apoptosis & [120] \\
\hline hsa-miR-506-3p & $>10$ & Cell proliferation and cancer & [121] \\
\hline hsa-miR-645 & $>10$ & Cell proliferation and cancer & [122] \\
\hline hsa-miR-129-5p & $>10$ & Inhibits the proliferation and metastasis of gastric cancer cells & {$[123]$} \\
\hline hsa-miR-516b-5p & $>10$ & Migration, cell proliferation, and cancer process & [124] \\
\hline hsa-miR-512-3p & $>10$ & Apoptosis and cell cycle & [125] \\
\hline hsa-miR-101-5p & $>10$ & Apoptosis and promotes cell proliferation & {$[126]$} \\
\hline hsa-miR-561-5p & $>10$ & Cell proliferation, $\mathrm{G}(1) / \mathrm{S}$ transition, and suppresses apoptosis & [127] \\
\hline hsa-miR-194-5p & $>10$ & Cell proliferation and cancer & [128] \\
\hline hsa-miR-329-3p & $>10$ & Proliferation, invasion, and suppresses cell apoptosis & [129] \\
\hline hsa-let-7i-3p & $>10$ & Coronary disease and cancer & [130] \\
\hline hsa-miR-129-2-3p & $>10$ & Proliferation, invasion, and apoptosis & [131] \\
\hline hsa-miR-548a-5p & $>10$ & Proliferation and inhibits apoptosis & [132] \\
\hline hsa-miR-887-5p & $>10$ & Pathways in cancer & [133] \\
\hline hsa-miR-99a-3p & $>10$ & Cell proliferation and pathways in cancer & {$[134]$} \\
\hline hsa-miR-487a-3p & $>10$ & Cell proliferation and cancer & [135] \\
\hline hsa-miR-378g & $>10$ & Cancer promotion & [136] \\
\hline hsa-miR-548at-5p & $>10$ & Neurodegenerative disease & {$[137]$} \\
\hline hsa-miR-374c-5p & $>10$ & Proliferation, apoptosis, and autophagy & [138] \\
\hline hsa-miR-106a-3p & $>10$ & Proliferation and apoptosis & [139] \\
\hline hsa-miR-92a-2-5p & $>10$ & Apoptosis and cell proliferation & [140] \\
\hline
\end{tabular}


Table 2. Cont.

\begin{tabular}{|c|c|c|c|}
\hline MicroRNA & Fold Change & Function & Reference \\
\hline hsa-miR-616-5p & $>10$ & Invasion, cell migration, and cancer & [141] \\
\hline hsa-miR-509-5p & $>10$ & Tumor suppressor & [142] \\
\hline hsa-miR-598-3p & $>10$ & Cancer process & [21] \\
\hline hsa-miR-873-5p & $>10$ & Cell migration and cancer & {$[143]$} \\
\hline hsa-miR-525-3p & $<10$ & Cancer cell migration & [21] \\
\hline hsa-miR-500a-5p & $<10$ & Cell apoptosis and proliferation & [144] \\
\hline hsa-miR-659-3p & $<10$ & Cell proliferation and cancer; apoptosis & [145] \\
\hline hsa-miR-526b-5p & $<10$ & Cell proliferation and cancer & [146] \\
\hline hsa-miR-764 & $<10$ & Cardiac diseases and cancer & [147] \\
\hline hsa-miR-934 & $<10$ & Cancer progression and inflammation & [148] \\
\hline hsa-miR-516a-5p & $<10$ & Cell proliferation and cancer & [149] \\
\hline hsa-miR-520f-3p & $<10$ & DNA repair & [150] \\
\hline hsa-miR-369-5p & $<10$ & Aerobic glycolysis and pathways in cancer & [151] \\
\hline hsa-miR-613 & $<10$ & Invasion and cell proliferation & [152] \\
\hline hsa-miR-411-3p & $<10$ & Proliferation and cancer & {$[153]$} \\
\hline hsa-miR-432-3p & $<10$ & Inflammation & [154] \\
\hline hsa-let-7c-3p & $<10$ & Apoptosis & [155] \\
\hline hsa-miR-671-5p & $<10$ & Proliferation and cell cycle & [156] \\
\hline hsa-miR-181d-5p & $<10$ & Proliferation and angiogenesis & [157] \\
\hline hsa-miR-192-5p & $<10$ & Hypertension and cancer & [158] \\
\hline hsa-let-7g-3p & $<10$ & Linked to oxidative stress, inflammation, and atherosclerosis & [159] \\
\hline hsa-miR-1-3p & $<10$ & Decreases tumor volume in a xenograft model & [68] \\
\hline hsa-miR-515-3p & $<10$ & Cell proliferation, migration, invasion, and induced apoptosis & {$[160]$} \\
\hline hsa-miR-320d & $<10$ & Apoptosis and cancer & [161] \\
\hline hsa-miR-548aa & $<10$ & Can alter the inflammatory responses & [162] \\
\hline hsa-miR-502-5p & $<10$ & Cell proliferation and invasion & [37] \\
\hline hsa-miR-758 & $<10$ & Proliferation and invasion & [163] \\
\hline hsa-miR-7-1-3p & $<10$ & Autophagy and cancer process & [164] \\
\hline hsa-miR-324-3p & $<10$ & Cell proliferation and cancer & [165] \\
\hline hsa-miR-520g-3p & $<10$ & DNA repair & [166] \\
\hline hsa-miR-576-5p & $<10$ & Cell invasion and cancer & [151] \\
\hline hsa-miR-520a-3p & $<10$ & $\begin{array}{l}\text { Inhibits tumor progression, indicating its potential role as a tumor } \\
\text { suppressor. }\end{array}$ & [167] \\
\hline hsa-miR-449b-3p & $<10$ & Proliferation & [168] \\
\hline hsa-miR-211-5p & $<10$ & Pathways in cancer & [169] \\
\hline hsa-miR-376a-3p & $<10$ & Coronary artery disease & [170] \\
\hline hsa-miR-939-3p & $<10$ & Pathways in cancer & {$[171]$} \\
\hline hsa-miR-214-3p & $<10$ & Inhibition of migration and proliferation & {$[172]$} \\
\hline hsa-miR-609 & $<10$ & Cardiovascular process & {$[173]$} \\
\hline hsa-miR-29a-5p & $<10$ & Cardiac myocytes and overall cardiac dysfunction & [174] \\
\hline
\end{tabular}


Table 2. Cont.

\begin{tabular}{|c|c|c|c|}
\hline MicroRNA & Fold Change & Function & Reference \\
\hline hsa-miR-449c-3p & $<10$ & Inhibits NSCLC cell progression & [175] \\
\hline hsa-miR-185-3p & $<10$ & Proliferation and invasion of cell & [176] \\
\hline hsa-miR-766-3p & $<10$ & Suppresses apoptosis and facilitates autophagy & [177] \\
\hline hsa-miR-486-5p & $<10$ & Regulation of heart contraction, muscle contraction, and ion channel activity & [53] \\
\hline hsa-miR-144 & $<10$ & Tumor inhibitors or tumor suppressors, proliferation, and apoptosis & [53] \\
\hline hsa-miR-664a-5p & $<10$ & Induces cell differentiation & [178] \\
\hline hsa-miR-32-3p & $<10$ & Atherosclerosis & [179] \\
\hline hsa-miR-224-3p & $<10$ & Cell proliferation and promotes apoptosis & [180] \\
\hline hsa-miR-130a-5p & $<10$ & Myocardial infarction & [181] \\
\hline hsa-miR-378i & $<10$ & $\begin{array}{c}\text { Metabolic pathways, mitochondrial energy homeostasis, and related } \\
\text { biological processes }\end{array}$ & [182] \\
\hline hsa-miR-642b-5p & $<10$ & Inflammation & [183] \\
\hline hsa-miR-668-3p & $<10$ & Progression of different types of cancer & [184] \\
\hline hsa-miR-18b-5p & $<10$ & Progression of different types of cancer; cardiac function & [185] \\
\hline hsa-miR-483-3p & $<10$ & Apoptosis & [186] \\
\hline hsa-miR-485-3p & $<10$ & Cell proliferation; pathways in cancer & [187] \\
\hline hsa-miR-200c-5p & $<10$ & Oxidative stress and cell apoptosis & [188] \\
\hline hsa-miR-126-5p & $<10$ & Linked to oxidative stress, inflammation, and atherosclerosis & [189] \\
\hline hsa-miR-26b-3p & $<10$ & Cell proliferation and invasion & [190] \\
\hline hsa-miR-378d & $<10$ & Proliferation and migration of cancer & [191] \\
\hline hsa-miR-526b-3p & $<10$ & Regulates the proliferation, invasion, and migration of cancer cells & [192] \\
\hline hsa-miR-575 & $<10$ & Oncogene & [193] \\
\hline hsa-miR-564 & $<10$ & Cell proliferation and invasion & [194] \\
\hline hsa-miR-513a-5p & $<10$ & Induced apoptosis & [195] \\
\hline hsa-miR-548i & $<10$ & Downregulates the inflammatory cytokines & [196] \\
\hline hsa-miR-188-5p & $<10$ & Cell proliferation and cancer promotion & [197] \\
\hline hsa-miR-563 & $<10$ & Cell proliferation and cancer promotion & [198] \\
\hline hsa-miR-139-3p & $<10$ & Proliferation and invasion & [199] \\
\hline hsa-miR-34a-5p & $<0.1$ & Inflammation & [200] \\
\hline hsa-miR-34b-5p & $<0.1$ & P53 effector, cell proliferation, and apoptosis & [201] \\
\hline hsa-miR-371b-5p & $<0.1$ & Cell proliferation and apoptosis & [202] \\
\hline hsa-let-7f-2-3p & $<0.1$ & Cell proliferation and apoptosis & {$[203,204]$} \\
\hline hsa-miR-557 & $<0.1$ & Tumor suppressor & [205] \\
\hline hsa-miR-574-5p & $<0.1$ & Cell cycle and cancer process & [206] \\
\hline hsa-miR-216a-3p & $<0.1$ & Cell proliferation and apoptosis & [207] \\
\hline hsa-miR-466 & $<0.1$ & Tumor suppressor & [208] \\
\hline hsa-miR-222-3p & $<0.1$ & Cell viability, migration, and invasion & [209] \\
\hline hsa-miR-586 & $<0.1$ & Cell proliferation, invasion, metastasis, and apoptosis & [210] \\
\hline hsa-miR-939-5p & $<0.1$ & Inflammation & [211] \\
\hline
\end{tabular}


Table 2. Cont.

\begin{tabular}{|c|c|c|c|}
\hline MicroRNA & Fold Change & Function & Reference \\
\hline hsa-miR-548b-3p & $<0.1$ & Proliferation, apoptosis, and mitochondrial function & [212] \\
\hline hsa-miR-517c-3p & $<0.1$ & Responses to stress; alterations in circulating glucose levels & [213] \\
\hline hsa-miR-630 & $<0.1$ & Oxidative damage and cell migration & [214] \\
\hline hsa-miR-544a & $<0.1$ & Pathways in cancer & [215] \\
\hline hsa-miR-603 & $<0.1$ & Proliferation, migration, invasion, and metastasis & [216] \\
\hline hsa-miR-552-5p & $<0.1$ & Cell proliferation & [217] \\
\hline hsa-miR-562 & $<0.1$ & Tumor suppressor & [218] \\
\hline hsa-miR-548 & $<0.1$ & Cancer cell proliferation, migration, and invasion & [219] \\
\hline hsa-miR-518a- & $<0.1$ & Tumor suppressor & [220] \\
\hline hsa-miR-433-5p & $<0.1$ & Cardiovascular process & [32] \\
\hline hsa-miR-138-5p & $<0.1$ & Cardiac function and pathological damage & [221] \\
\hline hsa-miR-548ad-5p & $<0.1$ & Cancer cell proliferation, migration, and invasion & [222] \\
\hline hsa-miR-450a-2-3p & $<0.1$ & Cell proliferation and cancer & [220] \\
\hline hsa-miR-548av-3p & $<0.1$ & Cancer cell proliferation, migration, and invasion & [223] \\
\hline hsa-miR-624-5p & $<0.1$ & Cell proliferation and cancer & [220] \\
\hline hsa-miR-553 & $<0.1$ & Cell proliferation and cancer & [224] \\
\hline hsa-miR-876-5p & $<0.1$ & Cell proliferation and cancer & [225] \\
\hline hsa-miR-190b & $<0.1$ & Autophagy and cell cycle & [226] \\
\hline hsa-miR-26a-2-3p & $<0.1$ & Cell cycle and cancer process & [227] \\
\hline hsa-miR-515-5p & $<0.1$ & Cardiac function and proliferation cells & [75] \\
\hline hsa-miR-195-3p & $<0.1$ & Cardiac function and proliferation cells & [228] \\
\hline hsa-miR-365b-5p & $<0.1$ & Inflammation and cell proliferation & [229] \\
\hline Hsa-miR-885-3p & $<0.1$ & Inflammation & [230] \\
\hline
\end{tabular}

Table 3. UV exposure.

\begin{tabular}{|c|c|c|c|}
\hline MicroRNA & Fold Variation & Functions & Reference \\
\hline hsa-miR-329-3p & $>10$ & Inhibits cell proliferation in glioma cells & [231] \\
\hline hsa-miR-520g-5p & $>10$ & DNA repair & [232] \\
\hline hsa-miR-216a- & $>10$ & $\begin{array}{l}\text { Regulates the proliferation, apoptosis, migration, and invasion of lung } \\
\text { cancer cells }\end{array}$ & [151] \\
\hline hsa-miR-548c-3p & $>10$ & Cancer cell proliferation, migration, and invasion & [233] \\
\hline hsa-miR-129-2-3p & $>10$ & Inhibits the proliferation and metastasis of gastric cancer cells & [220] \\
\hline hsa-miR-887-5p & $<10$ & Pathways in cancer & [124] \\
\hline hsa-miR-106a-3p & $>10$ & Involved in tumorigenesis and highly expressed in gastric cancer & [234] \\
\hline hsa-miR-616-5p & $>10$ & $\begin{array}{l}\text { Progression of bladder cancer by regulating cell proliferation, migration, } \\
\text { and apoptosis }\end{array}$ & [235] \\
\hline hsa-miR-509-5p & $>10$ & Tumor suppressive effects & [236] \\
\hline hsa-miR-648 & $>10$ & Post-transcriptional regulators of glioblastoma & [237] \\
\hline
\end{tabular}


Table 3. Cont.

\begin{tabular}{|c|c|c|c|}
\hline MicroRNA & Fold Variation & Functions & Reference \\
\hline hsa-miR-378h & $>10$ & $\begin{array}{l}\text { Metabolic pathways, mitochondrial energy homeostasis, and angiogenic } \\
\text { network in tumors }\end{array}$ & [238] \\
\hline hsa-miR-200c-5p & $>10$ & Upregulated by oxidative stress and induces endothelial cell apoptosis & [183] \\
\hline hsa-miR-525-3p & $<10$ & Pathways in cancer & [239] \\
\hline hsa-miR-488-3p & $<10$ & Pathways in cancer & {$[44]$} \\
\hline hsa-miR-101-5p & $<10$ & Regulates cell proliferation & [240] \\
\hline hsa-let-7g-3p & $<10$ & Modulates inflammatory responses; pathways in cancer & [241] \\
\hline hsa-miR-376a-2-5p & $<10$ & Pathways in cancer & [242] \\
\hline hsa-miR-640 & $<10$ & Pathways in cancer & [243] \\
\hline hsa-miR-300 & $<10$ & Controls stem cell function and inhibits differentiation & [244] \\
\hline hsa-miR-509-3p & $<10$ & Pathways in cancer & [245] \\
\hline hsa-miR-548au-5p & $<10$ & Pathways in cancer & [246] \\
\hline hsa-miR-337-3p & $<10$ & Pathways in cancer & [100] \\
\hline hsa-miR-411-3p & $<10$ & Pathways in cancer & [247] \\
\hline hsa-miR-494-3p & $<10$ & Mitochondrial biogenesis and pathways in cancer & [248] \\
\hline hsa-let-7e-3p & $<10$ & Pathways in cancer & [249] \\
\hline hsa-miR-144-3p & $<10$ & Regulates adipogenesis and pathways in cancer & [250] \\
\hline hsa-miR-196b-3p & $<10$ & Cell proliferation & [251] \\
\hline hsa-miR-10b-5p & $<10$ & Pathways in cancer & [102] \\
\hline hsa-miR-33a-5p & $<10$ & Associated with carcinogenesis & [252] \\
\hline hsa-miR-136-3p & $<10$ & $\begin{array}{l}\text { Cardiac function and pathological damage in myocardial tissue, } \\
\text { cardiomyocyte apoptosis, oxidative stress, and inflammatory response }\end{array}$ & [253] \\
\hline hsa-miR-143-3p & $<10$ & Pathways in cancer & [254] \\
\hline hsa-miR-762 & $<10$ & Modulates thyroxine-induced cardiomyocyte and pathways in cancer & [255] \\
\hline hsa-miR-582-5p & $<10$ & Cell proliferation & [256] \\
\hline hsa-miR-645 & $<10$ & Cell proliferation and apoptosis & [21] \\
\hline hsa-miR-411-5p & $<10$ & Cell proliferation and pathways in cancer & [257] \\
\hline hsa-miR-7-1-3p & $<10$ & Inhibits autophagy and induces apoptosis in glioblastoma & [258] \\
\hline hsa-miR-18a-3p & $<10$ & Progression of different types of cancer; cardiac function. & [259] \\
\hline hsa-miR-99a-3p & $<10$ & Cell proliferation and pathways in cancer & [186] \\
\hline hsa-miR-491-5p & $<10$ & Cell proliferation and pathways in cancer & [135] \\
\hline hsa-miR-19b-1-5p & $<10$ & Pathways in cancer & {$[260,261]$} \\
\hline hsa-miR-614 & $<10$ & Cell proliferation and pathways in cancer & [262] \\
\hline hsa-miR-493-5p & $<0.1$ & Cell proliferation & [263] \\
\hline hsa-miR-15b-3p & $<0.1$ & Proliferation, inflammation, and apoptosis & [264] \\
\hline hsa-miR-510-5p & $<0.1$ & Cell proliferation & [265] \\
\hline hsa-miR-485-5p & $<0.1$ & Cell proliferation and pathways in cancer & [266] \\
\hline hsa-miR-581 & $<0.1$ & Induces proliferation and migration & [188] \\
\hline hsa-miR-340-3p & $<0.1$ & Cell proliferation and pathways in cancer & [267] \\
\hline hsa-miR-708-5p & $<0.1$ & Cell proliferation and pathways in cancer & [268] \\
\hline
\end{tabular}


Table 3. Cont.

\begin{tabular}{|c|c|c|c|}
\hline MicroRNA & Fold Variation & Functions & Reference \\
\hline hsa-miR-548j-3p & $<0.1$ & Induces proliferation and migration & [269] \\
\hline hsa-miR-618 & $<0.1$ & Cell proliferation and pathways in cancer & [270] \\
\hline hsa-miR-885-3p & $<0.1$ & Inflammatory response and pathways in cancer & [271] \\
\hline hsa-miR-297 & $<0.1$ & Oncogene, inflammatory response, and apoptosis & [231] \\
\hline hsa-miR-518a-5p & $<0.1$ & Tumor suppressor & {$[272,273]$} \\
\hline hsa-let-7f-2-3p & $<0.1$ & Proliferation and apoptosis & [32] \\
\hline hsa-miR-519b-3p & $<0.1$ & Radiosensitivity of radio-resistant cells and pathways in cancer & [205] \\
\hline hsa-miR-27b-5p & $<0.1$ & Prevents atherosclerosis by inhibiting inflammatory responses & [274] \\
\hline hsa-miR-625-5p & $<0.1$ & Inflammation and inhibits cardiac hypertrophy & [275] \\
\hline hsa-miR-548ah-5p & $<0.1$ & Induces proliferation and migration & [276] \\
\hline hsa-miR-892c-3p & $<0.1$ & Pathways in cancer & [86] \\
\hline hsa-miR-373-3p & $<0.1$ & Inhibits autophagy & [277] \\
\hline hsa-miR-656-3p & $<0.1$ & Induces proliferation and migration & [278] \\
\hline hsa-miR-20a-3p & $<0.1$ & Proliferation and autophagy & [279] \\
\hline hsa-miR-518a-3p & $<0.1$ & Tumor suppressor & [280] \\
\hline hsa-miR-649 & $<0.1$ & Pathways in cancer & [32] \\
\hline hsa-miR-483-3p & $<0.1$ & Pathways in cancer and cardiac response & [281] \\
\hline hsa-miR-501-3p & $<0.1$ & Cell proliferation, clonogenicity, migration, and invasion & [282] \\
\hline hsa-miR-335-5p & $<0.1$ & Cell proliferation, migration, and invasion. & [283] \\
\hline hsa-miR-129-5p & $<0.1$ & Proliferation, invasion, and apoptosis & [284] \\
\hline hsa-miR-34c-5p & $<0.1$ & Proliferation and apoptosis & [132] \\
\hline hsa-miR-548ao-5p & $<0.1$ & Promotes proliferation and inhibits apoptosis & [202] \\
\hline hsa-miR-624-5p & $<0.1$ & Cell proliferation and pathways in cancer & [133] \\
\hline
\end{tabular}

MicroRNAs reported in Tables 1-3 were selected by both volcano plot analysis and Venn diagram data representation. These miRNAs represent the specific signature of each pollutant, being modulated both after short-term exposure (UV $20 \mathrm{~s}$, diesel $30 \mathrm{~min}$, and ozone $4 \mathrm{~h}$ ) and long-term exposure ( $24 \mathrm{~h}$ for all pollutants).

Fold variations reported in Tables 1-3 are the rate of signal intensity changes between treated and untreated samples at $24 \mathrm{~h}$.

The main biological pathways regulated by these miRNAs, as inferred from available literature, are also reported.

The main pathways targeted by tested pollutants were: apoptosis, cell cycle, and inflammation (Table 4).

Table 4. Number of the miRNAs involved in the pathways deregulated by each pollutant tested. Only miRNAs demonstrated to be involved in the pathways are included.

\begin{tabular}{cccc}
\hline & Diesel & Ozone & UV \\
\hline Apoptosis & 16 & 36 & 12 \\
\hline Cell cycle & 7 & 24 & 11 \\
\hline Inflammation & 11 & 21 & 7 \\
\hline DNA repair & 1 & 4 & 2 \\
\hline Pathways in cancer & 23 & 72 & 39 \\
\hline
\end{tabular}




\section{Discussion and Conclusions}

The constant exposure to oxidants, including ultraviolet (UV) radiation and other environmental pollutants, such as diesel fuel exhaust and ozone, makes the skin our first defense against the outdoor environment, and it is also the tissue more affected by outdoor stressors. The contribution of the now defined "exposome" to extrinsic skin aging and skin conditions is well accepted. Pollution is one of the main players included in the skin exposome [224]. It has been recently shown [285] that exposure to more pollutants can have an additive effect. This could be a consequence of the different mechanisms of action of each stressor based on its chemical/physical properties.

It is generally understood that the toxic effects of $\mathrm{O}_{3}$, although it is not a radical species, per se, are mediated through free radical reactions either directly by the oxidation of biomolecules to give classical radical species (hydroxyl radical) or by driving the radicaldependent production of cytotoxic nonradical species (aldehydes) [286].

$\mathrm{O}_{3}$ cannot penetrate the $\mathrm{SC}$, so it first interacts with the lipids present in the outermost layer of the skin, leading to the generation of a number of bioreactive species [287]. It can be suggested that reaction with the well-organized interstitial lipids and protein constituents of the outermost stratum corneum barrier, and the diffusion of bioreactive products from this tissue into the viable layers of the epidermis, may represent a contribution to the development/exacerbation of skin disorders associated with $\mathrm{O}_{3}$ exposure. Indeed, once these "mediators" can reach live cells (keratinocytes, fibroblasts, etc.), they can induce a cellular defensive and inflammatory response that leads to an inflammatory/oxidative vicious cycle, called OxInflammation [288]. Unless quenched by endogenous or exogenous mechanisms, this will damage the skin and compromise its barrier functions, contributing to extrinsic skin aging.

Different hypotheses have been proposed concerning the initiation of the PM's detrimental effects on cutaneous tissues. This could be due to an indirect effect by an outsideinside signaling cascade. PM, especially smaller particles, may carry metal ions and/or organic compounds such as polycyclic aromatic hydrocarbons (PAHs), which are highly lipophilic and can penetrate the skin surface [287]. This is in agreement with our observations. Moreover, PAHs are potent ligands for the AhR receptor, expressed by both keratinocytes and melanocytes, which upregulates proinflammatory mediators and increases ROS production [289].

In a previous study, we provided evidence that PM develops cutaneous damage not only directly once particles reach deeper layers in the epidermis but also indirectly by triggering a signaling pathway [290]. Oxidative stress and an inflammatory response seem to be important steps in the PM toxic mechanisms.

The solar spectrum reaching the surface of the earth is divided into three main segments based on wavelength: UVC (100-290 nm), UVB (290-320 nm), and UVA (320-400 $\mathrm{nm}$ ). Both UVA and UVB have acute and chronic effects on human skin [287]. It has been established that approximately $50 \%$ of UV-induced direct cellular injury accounts for the remainder of the damage [291-293].

Therefore, although UV, PM, and ozone have different mechanisms of action, they all have the common denominator of damage that can be summarized as oxidative stress.

This effect is not limited to a biochemical effect, but it has been shown that air pollutants modulate epigenetic states, ranging from DNA methylation to miRNAs expression [294].

The aim of this study was to evaluate the different miRNA cutaneous responses to the main pollutants to which our skin is exposed daily.

It was not surprising that there was a clear difference among the pollutants in terms of the modulated miRNAs and the pathways associated with the epigenetic variation.

We found that the main pathways affected by the analyzed pollutants were: apoptosis, cell cycle, inflammation, DNA repair, and cancer. Of note, apoptosis was not associated with $\mathrm{O}_{3}$ exposure, and this could be a consequence of the $\mathrm{O}_{3}$ mechanism of action, which leads 
to the generation of proinflammatory mediators $\left(\mathrm{H}_{2} \mathrm{O}_{2}\right.$ and aldehydes) less aggressively compared to UV and PM $[89,100]$

The ability of UV to induce DNA damage and subsequent apoptosis has been well demonstrated in the past, and our data confirm these results under the epigenetic mechanism as well. In addition, our data confirmed the involvement of $\mathrm{O}_{3}$ exposure in cutaneous inflammation, as previously demonstrated by $\mathrm{Xu}$ et al., where ER visit for skin inflammatory conditions perfectly correlated with increased ozone levels in urban cities $[17,20]$.

To confirm that the $\mathrm{O}_{3}$ epigenetic effect is tissue-specific (due to the different mediators generated by the interaction with different tissues), the work by [295] showed that the expression analysis of sputum samples revealed that $\mathrm{O}_{3}$ exposure significantly increased the expression levels of several miRNAs, namely miR-132, miR-143, miR-145, miR-199b-5p, miR-222, miR-223, miR-25, miR-424, and miR-582-5p that while not detected in our analysis were still involved in inflammation. A quite recent work suggests that the main effect of PM on the skin is due to the absorption of PAHs, which can lead to skin barrier perturbation and damage [296]. PAH exposure has been already associated with epigenetic variation related mainly to DNA methylation.

In the present study, we have shown for the first time that PAH (present in diesel particles) can affect cutaneous epigenetics related to miRNA expression, highlighting the possible detrimental effect that those compounds can have on the skin [61]. The timerelated kinetic differences in miRNA expression at 0 and $24 \mathrm{~h}$ reflect the different nature of the tested pollutants.

Ozone is a volatile gas; accordingly, its interaction with the skin induces effects on a short-term basis because this gas is neither metabolized nor entrapped into skin layers. UV radiation induces short-term alteration triggering reactive mechanisms (DNA repair, etc.), requiring at least $8 \mathrm{~h}$ to be activated by the modulation of the microRNA machinery. MicroRNAs are highly sensitive to environmental stressors, as is well demonstrated in the lung for cigarette smoke [297] and airborne pollutants [298]. However, this issue has not yet been explored in the skin. The presented results herein provide experimental evidence that human skin undergoes dramatic changes in its physiological microRNA profile when exposed to environmental pollutants, either physical or chemical.

Diesel fumes are well known to induce genotoxic damage and DNA adduct formation [299], as well as microRNA alteration in the lung [300]. Diesel extracts can induce cancer in mouse skin [301]. The carcinogenic effect of diesel fumes is mainly due to the presence in this mixture of potent chemical genotoxic carcinogens such as nitropyrenes [302]. Indeed, epigenome regulation performed by the microRNA machinery can silence the expression of mutated oncogenes, thus defending our organism from the progression of the carcinogenic process. Only when genomic damage accumulates in the presence of irreversible alteration of the microRNA machinery does cancer occur [303].

Accordingly, the demonstration that microRNA are dramatically altered in human skin shows that diesel fumes are a complete skin carcinogen inducing both genomic and epigenomic alterations. The carcinogenicity of diesel fumes is exerted by the phase I and II metabolic reaction of its chemical components with particular reference to polycyclic aromatic hydrocarbons. This situation, together with the limited metabolic potential of the skin as compared to other tissues, explains why microRNA alterations reach the maximum level only after $40 \mathrm{~h}$ of exposure. The carcinogenicity of diesel fumes is confirmed by the finding that the majority $(40 \%)$ of altered microRNA is involved in carcinogenesis processes, while only a minority is involved in defensive processes such as apoptosis (22\%) and DNA repair $(4 \%)[73,76]$.

Ozone displays an immediate effect on skin microRNA that does not increase after $24 \mathrm{~h}$ from the exposure. This finding indicates that adaptive mechanisms are triggered by ozone. Skin is well equipped with antioxidant defenses requiring some time to be activated. This situation is confirmed by the finding that the majority (31\%) of altered microRNA is involved in defensive mechanisms allowing removal of damaged cells (apoptosis) and DNA 
repair ( $8 \%$, i.e., two-fold more than diesel fumes), while only a minority in carcinogenesis (20\%, i.e., two-fold less than diesel fumes).

UV radiation is carcinogenic, as demonstrated by the finding that this exposure induces the most dramatic alterations of microRNA involved in carcinogenesis (45\%) compared to diesel fume and ozone.

Furthermore, UV displays a variety of other adverse biological effects, including cell loss by apoptosis, cell proliferation to replace lost cells, and inflammation. In this regard, microRNA alteration overlaps the main function of genes whose expression undergoes upregulation, as demonstrated in mouse skin [299].

Conversely, only a minority (7\%) of microRNA involved in DNA repair are activated in human skin after 24 and $48 \mathrm{~h}$. This situation is different from those reported in vivo in mouse skin after long-term exposure that activated a variety of genes involved in base excision (XP) and nucleotide excision (OGG1) DNA repair [304]. This finding indicates that only long-term exposure to UV is effective in activating defensive DNA repair, while exposures to high doses for a short time results in a lack of DNA repair activation. Because of this situation, sunburns, indicating the occurrence of UV exposure in the absence of effective activation of DNA and protein repair, represent a major risk factor for cancer development.

A limitation of the presented study is that skin biopsies were collected from three subjects only. Future studies using a wider number of subjects are necessary to explore the interindividual variation occurring in the miRNA of human skin when exposed to environmental pollutants.

\section{Conclusions}

In conclusion, our results provide experimental evidence in human skin that microRNA machinery is altered by exposure to environmental pollutants. This situation occurs regarding either chemical pollutants, such as diesel fumes and ozone, or exciting radiation, such as UV. MicroRNA alteration, on a short-term basis, represents an adaptive event triggering defensive mechanisms such as DNA repair and apoptosis, attenuating the consequences of molecular damage induced in the skin by environmental stressors. Whenever microRNA alterations persist for a long time because of continuous exposure to environmental stressors, microRNA defensive function is neutralized, thus leaving the pathology or even carcinogenesis process to develop. Our findings demonstrate that skin has potent microRNA machinery used to face exposure to environmental pollutants. The alteration induced in skin microRNA undergoes a signature specific to the environmental pollutant involved.

Author Contributions: Conceptualization, G.V. and A.I.; methodology A.P., S.C. and E.P. validation A.P. and A.I.; investigation G.V., resources, and data curation, and; writing - original draft preparation A.P., G.V. and A.I. and writing-review and editing all authors; visualization all authors, supervision A.I.; project administration, A.I. and G.V. and funding acquisition A.I. All authors have read and agreed to the published version of the manuscript.

Funding: This research was partially supported by the Italian Association for Cancer Research (AIRC, IG2017-20699 to A.I.).

Institutional Review Board Statement: Ethical review was waived for this study, due to the fact that human skin was obtained from cosmetic/elective surgery and was collected from consented donors under IRB approved protocols at facilities located in the continental United States.

Informed Consent Statement: As reported already in our recent Pambianchi E. et al., Antioxidants (Basel). 2021 Nov 30;10(12):1928, doi:10.3390/antiox10121928.

Data Availability Statement: The datasets used and/or analyzed during the current study are available in Gene Expression Omnibus (http:/ / www.ncbi.nlm.nih.gov/geo); GEO number accession requested, 15 March 2022).

Conflicts of Interest: The authors declare no conflict of interest. 


\section{References}

1. Lelieveld, J.; Pozzer, A.; Pöschl, U.; Fnais, M.; Haines, A.; Münzel, T. Loss of life expectancy from air pollution compared to other risk factors: A worldwide perspective. Cardiovasc. Res. 2020, 116, 1910-1917. [CrossRef] [PubMed]

2. World Health Organization (WHO). WHO's Urban Ambient Air Pollution Database - Update 2016; WHO: Geneva, Switzerland, 2016.

3. Fuchs, E. Epithelial Skin Biology. Three Decades of Developmental Biology, a Hundred Questions Answered and a Thousand New Ones to Address. Curr. Top. Dev. Biol. 2016, 116, 357-374. [CrossRef] [PubMed]

4. Feingold, K.R.; Schmuth, M.; Elias, P.M. The regulation of permeability barrier homeostasis. J. Investig. Dermatol. 2007, 127, 1574-1576. [CrossRef]

5. Valacchi, G.; Magnani, N.; Woodby, B.; Ferreira, S.M.; Evelson, P. Particulate Matter Induces Tissue OxInflammation: From Mechanism to Damage. Antioxid. Redox Signal. 2020, 33, 308-326. [CrossRef] [PubMed]

6. Criteria Air Pollutants. Available online: https://www.epa.gov/criteria-air-pollutants (accessed on 30 September 2021).

7. Fuks, K.B.; Hüls, A.; Sugiri, D.; Altug, H.; Vierkötter, A.; Abramson, M.J.; Goebel, J.; Wagner, G.G.; Demuth, I.; Krutmann, J.; et al. Tropospheric ozone and skin aging: Results from two German cohort studies. Environ. Int. 2019, 124, 139-144. [CrossRef]

8. Xu, F.; Yan, S.; Wu, M.; Li, F.; Xu, X.; Song, W.; Zhao, J.; Xu, J.; Kan, H. Ambient ozone pollution as a risk factor for skin disorders. Br. J. Dermatol. 2011, 165, 224-225. [CrossRef]

9. Kousha, T.; Valacchi, G. The air quality health index and emergency department visits for urticaria in Windsor, Canada. J. Toxicol. Environ. Health Part A Curr. Issues 2015, 78, 524-533. [CrossRef]

10. Valacchi, G.; Porada, E.; Rowe, B.H. Ambient ozone and bacterium streptococcus: A link between cellulitis and pharyngitis. Int. J. Occup. Med. Environ. Health 2015, 28, 771-774. [CrossRef]

11. Lademann, J.; Otberg, N.; Jacobi, U.; Hoffman, R.M.; Blume-Peytavi, U. Follicular penetration and targeting. J. Investig. Dermatol. Symp. Proc. 2005, 10, 301-303. [CrossRef]

12. Dijkhoff, I.M.; Drasler, B.; Karakocak, B.B.; Petri-Fink, A.; Valacchi, G.; Eeman, M.; Rothen-Rutishauser, B. Impact of airborne particulate matter on skin: A systematic review from epidemiology to in vitro studies. Part. Fibre Toxicol. 2020, 17, 35. [CrossRef]

13. Ferrara, F.; Woodby, B.; Pecorelli, A.; Schiavone, M.L.; Pambianchi, E.; Messano, N.; Therrien, J.P.; Choudhary, H.; Valacchi, G. Additive effect of combined pollutants to UV induced skin OxInflammation damage. Evaluating the protective topical application of a cosmeceutical mixture formulation. Redox Biol. 2020, 34, 1014481. [CrossRef] [PubMed]

14. Plusquin, M.; Guida, F.; Polidoro, S.; Vermeulen, R.; Raaschou-Nielsen, O.; Campanella, G.; Hoek, G.; Kyrtopoulos, S.A.; Georgiadis, P.; Naccarati, A.; et al. DNA methylation and exposure to ambient air pollution in two prospective cohorts. Environ. Int. 2017, 108, 127-136. [CrossRef] [PubMed]

15. Ding, R.; Jin, Y.; Liu, X.; Zhu, Z.; Zhang, Y.; Wang, T.; Xu, Y. Characteristics of DNA methylation changes induced by traffic-related air pollution. Mutat. Res. Genet. Toxicol. Environ. Mutagen. 2016, 15, 46-53. [CrossRef] [PubMed]

16. Xu, C.J.; Söderhäll, C.; Bustamante, M.; Baïz, N.; Gruzieva, O.; Gehring, U.; Mason, D.; Chatzi, L.; Basterrechea, M.; Llop, S.; et al. DNA methylation in childhood asthma: An epigenome-wide meta-analysis. Lancet Respir. Med. 2018, 6, 379-388. [CrossRef]

17. Alfano, R.; Herceg, Z.; Nawrot, T.S.; Chadeau-Hyam, M.; Ghantous, A.; Plusquin, M. The Impact of Air Pollution on Our Epigenome: How Far Is the Evidence? (A Systematic Review). Curr. Environ. Health Rep. 2018, 5, 544-578. [CrossRef]

18. Weinhold, B. Epigenetics: The science of change. Environ. Health Perspect. 2006, 114, 160-167. [CrossRef]

19. Jin, B.; Li, Y.; Robertson, K.D. DNA methylation: Superior or subordinate in the epigenetic hierarchy? Genes Cancer 2011, 2 , 607-617. [CrossRef]

20. Breton, C.V.; Marutani, A.N. Air Pollution and Epigenetics: Recent Findings. Curr. Environ. Health Rep. 2014, 1, 35-45. [CrossRef]

21. Chuang, J.C.; Jones, P.A. Epigenetics and microRNAs. Pediatr. Res. 2007, 61, 24-29. [CrossRef]

22. Cancer, I.A. IARC Monographs on the Evaluation of Carcinogenic Risks to Humans, No. 100D.; World Health Organization: Geneva, Switzerland, 2012; Volume 100D, p. 341. ISBN 978-9283213215.

23. Rooks, M.G.; Veiga, P.; Wardwell-Scott, L.H.; Tickle, T.; Segata, N.; Michaud, M.; Gallini, C.A.; Beal, C.; Van Hylckama-Vlieg, J.E.T.; Ballal, S.A.; et al. Gut microbiome composition and function in experimental colitis during active disease and treatment-induced remission. ISME J. 2014, 8, 1403-1417. [CrossRef]

24. Guo, B.; Hui, Q.; Xu, Z.; Chang, P.; Tao, K. miR-495 inhibits the growth of fibroblasts in hypertrophic scars. Aging 2019, 11, 2898-2910. [CrossRef]

25. Jun, H.; Ying, H.; Daiwen, C.; Bing, Y.; Xiangbing, M.; Ping, Z.; Jie, Y.; Zhiqing, H.; Junqiu, L. MIR-628, a microRNA that is induced by Toll-like receptor stimulation, regulates porcine innate immune responses. Sci. Rep. 2015, 5, 1-10. [CrossRef]

26. Chen, H.; Ji, X.; She, F.; Gao, Y.; Tang, P. MIR-628-3p regulates osteoblast differentiation by targeting RUNX2: Possible role in atrophic non-union. Int. J. Mol. Med. 2017, 39, 279-286. [CrossRef] [PubMed]

27. Dong, P.; Xiong, Y.; Yue, J.; Xu, D.; Ihira, K.; Konno, Y.; Kobayashi, N.; Todo, Y.; Watari, H. Long noncoding RNA NEAT1 drives aggressive endometrial cancer progression via miR-361-regulated networks involving STAT3 and tumor microenvironmentrelated genes. J. Exp. Clin. Cancer Res. 2019, 8, 38-295. [CrossRef] [PubMed]

28. Zhang, T.; Cai, X.; Li, Q.; Xue, P.; Chen, Z.; Dong, X.; Xue, Y. Hsa-miR-875-5p exerts tumor suppressor function through down-regulation of EGFR in colorectal carcinoma (CRC). Oncotarget 2016, 7, 42225-42240. [CrossRef]

29. Kang, N.; Ou, Y.; Wang, G.; Chen, J.; Li, D.; Zhan, Q. miR-875-5p exerts tumor-promoting function via down-regulation of CAPZA1 in esophageal squamous cell carcinoma. PeerJ 2021, 9, e10020. [CrossRef] 
30. Liang, J.-J.; Wang, J.-Y.; Zhang, T.-J.; An, G.-S.; Ni, J.-H.; Li, S.-Y.; Jia, H.-T. MiR-509-3-5p-NONHSAT112228.2 Axis Regulates p21 and Suppresses Proliferation and Migration of Lung Cancer Cells. Curr. Top. Med. Chem. 2020, 20, 835-846. [CrossRef]

31. Ram Kumar, R.M.; Boro, A.; Fuchs, B. Involvement and Clinical Aspects of MicroRNA in Osteosarcoma. Int. J. Mol. Sci. 2016, 17, 877. [CrossRef]

32. Yang, H.; Ren, J.; Bai, Y.; Jiang, J.; Xiao, S. Microrna-518-3p suppresses cell proliferation, invasiveness, and migration in colorectal cancer via targeting trip4. Biochem. Cell Biol. 2020, 98, 575-582. [CrossRef]

33. Zhao, Y.; Lukiw, W.J. Bacteroidetes Neurotoxins and Inflammatory Neurodegeneration. Mol. Neurobiol. 2018, 55, 9100-9107. [CrossRef]

34. Lu, L.; Zhang, H.; Dong, W.; Peng, W.; Yang, J. MiR-381 negatively regulates cardiomyocyte survival by suppressing Notch signaling. Vitr. Cell. Dev. Biol. Anim. 2018, 54, 610-619. [CrossRef]

35. Reddy, S.D.N.; Pakala, S.B.; Ohshiro, K.; Rayala, S.K.; Kumar, R. MicroRNA-661, a c/EBP $\alpha$ target, inhibits metastatic tumor antigen 1 and regulates its functions. Cancer Res. 2009, 69, 5639-5642. [CrossRef] [PubMed]

36. Yonemori, K.; Seki, N.; Idichi, T.; Kurahara, H.; Osako, Y.; Koshizuka, K.; Arai, T.; Okato, A.; Kita, Y.; Arigami, T.; et al. The microRNA expression signature of pancreatic ductal adenocarcinoma by RNA sequencing: Anti-tumour functions of the microRNA-216 cluster. Oncotarget 2017, 8, 70097-70115. [CrossRef] [PubMed]

37. Son, G.H.; Kim, Y.; Lee, J.J.; Lee, K.Y.; Ham, H.; Song, J.E.; Park, S.T.; Kim, Y.H. MicroRNA-548 regulates high mobility group box 1 expression in patients with preterm birth and chorioamnionitis. Sci. Rep. 2019, 9, 19746. [CrossRef] [PubMed]

38. Treiber, T.; Treiber, N.; Meister, G. Regulation of microRNA biogenesis and its crosstalk with other cellular pathways. Nat. Rev. Mol. Cell Biol. 2019, 20, 5-20. [CrossRef] [PubMed]

39. Wu, Z.H.; Huang, K.H.; Liu, K.; Wang, G.T.; Sun, Q. DGCR5 induces osteogenic differentiation by up-regulating Runx2 through miR-30d-5p. Biochem. Biophys. Res. Commun. 2018, 505, 426-431. [CrossRef] [PubMed]

40. Xu, Y.; Wu, D.; Jiang, Z.; Zhang, Y.; Wang, S.; Ma, Z.; Hui, B.; Wang, J.; Qian, W.; Ge, Z.; et al. MiR-616-3p modulates cell proliferation and migration through targeting tissue factor pathway inhibitor 2 in preeclampsia. Cell Prolif. 2018, 51, e12490. [CrossRef]

41. Ntoumou, E.; Tzetis, M.; Braoudaki, M.; Lambrou, G.; Poulou, M.; Malizos, K.; Stefanou, N.; Anastasopoulou, L.; Tsezou, A. Serum microRNA array analysis identifies miR-140-3p, miR-33b-3p and miR-671-3p as potential osteoarthritis biomarkers involved in metabolic processes. Clin. Epigenetics 2017, 12, 9-127. [CrossRef]

42. Sun, S.; Su, C.; Zhu, Y.; Li, H.; Liu, N.; Xu, T.; Sun, C.; Lv, Y. MicroRNA-544a Regulates Migration and Invasion in Colorectal Cancer Cells via Regulation of Homeobox A10. Dig. Dis. Sci. 2016, 61, 2535-2544. [CrossRef]

43. Shin, C.-H.; Byun, J.; Lee, K.; Kim, B.; Noh, Y.K.; Tran, N.L.; Park, K.; Kim, S.-H.; Kim, T.H.; Oh, S.J. Exosomal miRNA-19a and miRNA-614 Induced by Air Pollutants Promote Proinflammatory M1 Macrophage Polarization via Regulation of ROR $\alpha$ Expression in Human Respiratory Mucosal Microenvironment. J. Immunol. 2020, 205, 3179-3190. [CrossRef]

44. Xiong, G.; Zhang, J.; Zhang, Y.; Pang, X.; Wang, B.; Zhang, Y. Circular RNA_0074027 participates in cell proliferation, apoptosis and metastasis of colorectal cancer cells through regulation of miR-525-3p. Mol. Med. Rep. 2021, 23, 324. [CrossRef] [PubMed]

45. Templin, C.; Volkmann, J.; Emmert, M.Y.; Mocharla, P.; Müller, M.; Kraenkel, N.; Ghadri, J.R.; Meyer, M.; Styp-Rekowska, B.; Briand, S.; et al. Increased proangiogenic activity of mobilized CD34 + progenitor cells of patients with acute ST-segment-elevation myocardial infarction: Role of differential MicroRNA-378 expression. Arterioscler. Thromb. Vasc. Biol. 2017, 37, 341-349. [CrossRef]

46. Wang, H.; Chen, X.; Yang, B.; Xia, Z.; Chen, Q. MiR-924 as a tumor suppressor inhibits non-small cell lung cancer by inhibiting RHBDD1/Wnt/ $\beta$-catenin signaling pathway. Cancer Cell Int. 2020, 8, 20-49. [CrossRef] [PubMed]

47. Wang, X.; Tan, Y.; Xu, B.; Lu, L.; Zhao, M.; Ma, J.; Liang, H.; Liu, J.; Yu, S. GPR30 Attenuates Myocardial Fibrosis in Diabetic Ovariectomized Female Rats: Role of iNOS Signaling. DNA Cell Biol. 2018, 37, 821-830. [CrossRef] [PubMed]

48. Shuai, F.; Wang, B.; Dong, S. MiR-522-3p promotes tumorigenesis in human colorectal cancer via targeting bloom syndrome protein. Oncol. Res. 2018, 26, 1113-1121. [CrossRef]

49. Vettori, A.; Pompucci, G.; Paolini, B.; Del Ciondolo, I.; Bressan, S.; Dundar, M.; Kenanoğlu, S.; Unfer, V.; Bertelli, M. Genetic background, nutrition and obesity: A review. Eur. Rev. Med. Pharmacol. Sci. 2019, 23, 1751-1761. [CrossRef]

50. Wang, L.; Sun, M.; Cao, Y.; Ma, L.; Shen, Y.; Velikanova, A.A.; Li, X.; Sun, C.; Zhao, Y. miR-34a regulates lipid metabolism by targeting SIRT1 in non-alcoholic fatty liver disease with iron overload. Arch. Biochem. Biophys. 2020, 695, 108642. [CrossRef]

51. Xiao, K.; Luo, X.; Wang, X.; Gao, Z. MicroRNA-185 regulates transforming growth factor- $\beta 1$ and collagen- 1 in hypertrophic scar fibroblasts. Mol. Med. Rep. 2017, 15, 1489-1496. [CrossRef]

52. Li, K.P.; Fang, Y.P.; Liao, J.Q.; Duan, J.D.; Feng, L.G.; Luo, X.Z.; Liang, Z.J. Upregulation of miR-598 promotes cell proliferation and cell cycle progression in human colorectal carcinoma by suppressing INPP5E expression. Mol. Med. Rep. 2018, 17, $2991-2997$. [CrossRef]

53. Xiao, Y. MiR-486-5p inhibits the hyperproliferation and production of collagen in hypertrophic scar fibroblasts via IGF1/PI3K/AKT pathway. J. Dermatolog. Treat. 2020, 32, 973-982. [CrossRef]

54. Pedersen, I.M.; Cheng, G.; Wieland, S.; Volinia, S.; Croce, C.M.; Chisari, F.V.; David, M. Interferon modulation of cellular microRNAs as an antiviral mechanism. Nature 2007, 449, 919-922. [CrossRef] [PubMed]

55. Feng, H.J.; Ouyang, W.; Liu, J.H.; Sun, Y.G.; Hu, R.; Huang, L.H.; Xian, J.L.; Jing, C.F.; Zhou, M.J. Global microRNA profiles and signaling pathways in the development of cardiac hypertrophy. Braz. J. Med. Biol. Res. 2014, 47, 361-368. [CrossRef] [PubMed] 
56. Chaudhari, U.; Nemade, H.; Gaspar, J.A.; Hescheler, J.; Hengstler, J.G.; Sachinidis, A. MicroRNAs as early toxicity signatures of doxorubicin in human-induced pluripotent stem cell-derived cardiomyocytes. Arch. Toxicol. 2016, 90, 3087-3098. [CrossRef]

57. Xia, X.; Wang, S.; Ni, B.; Xing, S.; Cao, H.; Zhang, Z.; Yu, F.; Zhao, E.; Zhao, G. Hypoxic gastric cancer-derived exosomes promote progression and metastasis via MiR-301a-3p/PHD3/HIF-1 $\alpha$ positive feedback loop. Oncogene 2020, 39, 6231-6244. [CrossRef]

58. Zhang, L.; Li, J.; Cui, L.; Shang, J.; Tian, F.; Wang, R.; Xing, G. Retraction notice to MicroRNA-30b promotes lipopolysaccharideinduced in $\mathrm{fl}$ ammatory injury and alleviates autophagy through JNK and NF- $\mathrm{\kappa}$ B. Biomed. Pharmacother. 2020, $128,266021$.

59. Guan, C.; Wang, Y. LncRNA CASC9 attenuates lactate dehydrogenase-mediated oxidative stress and inflammation in spinal cord injury via sponging miR-383-5p. Inflammation 2021, 44, 923-933. [CrossRef]

60. Sun, R.; Ge, L.; Cao, Y.; Wu, W.; Wu, Y.; Zhu, H.; Li, J.; Yu, D. Corrigendum to "MiR-429 regulates blood-spinal cord barrier permeability by targeting Krüppel-like factor 6". Biochem. Biophys. Res. Commun. 2020, 525, 740-746. [CrossRef]

61. Chen, X.F.; Zhang, L.J.; Zhang, J.; Dou, X.; Shao, Y.; Jia, X.J.; Zhang, W.; Yu, B. MiR-151a is involved in the pathogenesis of atopic dermatitis by regulating interleukin-12 receptor $\beta 2$. Exp. Dermatol. 2018, 27, 427-432. [CrossRef]

62. Xiao, S.; Zhang, M.; Liu, C.; Wang, D. MiR-514 attenuates proliferation and increases chemoresistance by targeting ATP binding cassette subfamily in ovarian cancer. Mol. Genet. Genom. 2018, 293, 1159-1167. [CrossRef]

63. Chu, H.T.; Li, L.; Jia, M.; Diao, L.L.; Li, Z.B. Correlation between serum microRNA-136 levels and RAAS biochemical markers in patients with essential hypertension. Eur. Rev. Med. Pharmacol. Sci. 2020, 24, 11761-11767. [CrossRef]

64. Mishima, Y.; Stahlhut, C.; Giraldez, A.J. miR-1-2 Gets to the Heart of the Matter. Cell 2007, 20, 247-249. [CrossRef] [PubMed]

65. Qi, B.; Dong, Y.; Qiao, X.L. Effects of miR-18a on proliferation and apoptosis of gastric cancer cells by regulating RUNX1. Eur. Rev. Med. Pharmacol. Sci. 2020, 24, 9957-9964. [CrossRef] [PubMed]

66. Jin, H.; Yu, M.; Lin, Y.; Hou, B.; Wu, Z.; Li, Z.; Sun, J. MiR-502-3P suppresses cell proliferation, migration, and invasion in hepatocellular carcinoma by targeting SET. Onco. Targets. Ther. 2016, 9, 3281-3289. [CrossRef] [PubMed]

67. Zhang, Y.; Chu, X.; Wei, Q. Mir-451 promotes cell apoptosis and inhibits autophagy in pediatric acute myeloid leukemia by targeting hmgb1. J. Environ. Pathol. Toxicol. Oncol. 2021, 40, 45-53. [CrossRef]

68. Rodosthenous, R.S.; Coull, B.A.; Lu, Q.; Vokonas, P.S.; Schwartz, J.D.; Baccarelli, A.A. Ambient particulate matter and microRNAs in extracellular vesicles: A pilot study of older individuals. Part. Fibre Toxicol. 2016, 13, 13. [CrossRef]

69. Wang, Z.; Liu, W.; Wang, C.; Ai, Z. Mir-873-5p inhibits cell migration and invasion of papillary thyroid cancer via regulation of CXCL16. Onco. Targets. Ther. 2020, 13, 1037-1046. [CrossRef]

70. Tu, H.; Wei, G.; Cai, Q.; Chen, X.X.; Sun, Z.; Cheng, C.; Zhang, L.; Feng, Y.; Zhou, H.; Zhou, B.; et al. MicroRNA-212 inhibits hepatocellular carcinoma cell proliferation and induces apoptosis by targeting FOXAI. Onco. Targets. Ther. 2015, 24, $2227-2235$. [CrossRef]

71. Zhang, X.; Zhang, Y.; Dou, L. MiR-552 promotes the proliferation and metastasis of cervical cancer cells through targeting MUC15 pathway. J. Cancer 2021, 12, 6094-6104. [CrossRef]

72. Fang, L.; Xu, X.; Lu, Y.; Wu, Y.Y.; Li, J.J. MicroRNA-495 attenuates proliferation and inflammatory response in rheumatoid arthritis fibroblast-like synoviocytes through attenuating $\beta$-catenin pathway. J. Biol. Regul. Homeost. Agents 2020, 34, 837-844. [CrossRef]

73. Zhang, K.; Guo, L. MiR-767 promoted cell proliferation in human melanoma by suppressing CYLD expression. Gene 2018, 641, 272-278. [CrossRef]

74. Sun, L.; Trajkovski, M. MiR-27 orchestrates the transcriptional regulation of brown adipogenesis. Metabolism 2014, 63, $272-282$. [CrossRef] [PubMed]

75. Si, Z.; Yu, L.; Jing, H.; Wu, L.; Wang, X. Oncogenic lncRNA ZNF561-AS1 is essential for colorectal cancer proliferation and survival through regulation of miR-26a-3p/miR-128-5p-SRSF6 axis. J. Exp. Clin. Cancer Res. 2021, 40, 78. [CrossRef] [PubMed]

76. Tao, X.; Yang, X.; Wu, K.; Yang, L.; Huang, Y.; Jin, Q.; Chen, S. miR-629-5p promotes growth and metastasis of hepatocellular carcinoma by activating $\beta$-catenin. Exp. Cell Res. 2019, 15, 124-130. [CrossRef] [PubMed]

77. Liu, X.; Gan, L.; Zhang, J. miR-543 inhibites cervical cancer growth and metastasis by targeting TRPM7. Chem. Biol. Interact. 2019, 302, 83-92. [CrossRef]

78. Zhang, M.; Muralimanoharan, S.; Wortman, A.C.; Mendelson, C.R. Primate-specific miR-515 family members inhibit key genes in human trophoblast differentiation and are upregulated in preeclampsia. Proc. Natl. Acad. Sci. USA 2016, 113, 7069-7076. [CrossRef]

79. Witwer, K.W.; Sarbanes, S.L.; Liu, J.; Clements, J.E. A plasma microRNA signature of acute lentiviral infection: Biomarkers of central nervous system disease. AIDS 2011, 25, 2057-2067. [CrossRef]

80. Li, B.; Wang, Y.; Li, S.; He, H.; Sun, F.; Wang, C.; Lu, Y.; Wang, X.; Tao, B. Decreased expression of miR-378 correlates with tumor invasiveness and poor prognosis of patients with glioma. Int. J. Clin. Exp. Pathol. 2015, 8, 7016-7021.

81. Li, Q.; Tian, Y.; Liang, Y.; Li, C. CircHIPK3/miR-876-5p/PIK3R1 axis regulates regulation proliferation, migration, invasion, and glutaminolysis in gastric cancer cells. Cancer Cell Int. 2020, 13, 391. [CrossRef]

82. Guo, M.; Jiang, Z.; Zhang, X.; Lu, D.; Ha, A.D.; Sun, J.; Du, W.; Wu, Z.; Hu, L.; Khadarian, K.; et al. miR-656 inhibits glioma tumorigenesis through repression of BMPR1A. Carcinogenesis 2014, 35, 1698-1706. [CrossRef]

83. Lv, L.; Wang, X.; Ma, T. MicroRNA-944 inhibits the malignancy of hepatocellular carcinoma by directly targeting IGF-1R and deactivating the PI3K/Akt signaling pathway. Cancer Manag. Res. 2019, 11, 2531-2543. [CrossRef]

84. Zhang, W.; Zhong, B.; Zhang, C.; Luo, C.; Zhan, Y. miR-373 regulates inflammatory cytokine-mediated chondrocyte proliferation in osteoarthritis by targeting the P2X7 receptor. FEBS Open Bio 2018, 8, 325-331. [CrossRef] [PubMed] 
85. Aqeilan, R.I.; Calin, G.A.; Croce, C.M. MiR-15a and miR-16-1 in cancer: Discovery, function and future perspectives. Cell Death Differ. 2010, 17, 215-220. [CrossRef] [PubMed]

86. Yang, Z.; Wei, Z.; Wu, X.; Yang, H. Screening of exosomal miRNAs derived from subcutaneous and visceral adipose tissues: Determination of targets for the treatment of obesity and associated metabolic disorders. Mol. Med. Rep. 2018, 18, 3314-3324. [CrossRef] [PubMed]

87. Xu, Y.; Wang, L.; Jiang, L.; Zhang, X. Novel MicroRNA Biomarkers, miR-142-5p, miR-550a, miR-1826, and miR-1201, Were Identified for Primary Melanoma. J. Comput. Biol. 2020, 27, 815-824. [CrossRef]

88. Jiang, X.; Huang, H.; Li, Z.; He, C.; Li, Y.; Chen, P.; Gurbuxani, S.; Arnovitz, S.; Hong, G.M.; Price, C.; et al. miR-495 is a tumor-suppressor microRNA down-regulated in MLL-rearranged leukemia. Proc. Natl. Acad. Sci. USA 2012, 109, 19397-19402. [CrossRef]

89. Wei, Q.; Tu, Y.; Zuo, L.; Zhao, J.; Chang, Z.; Zou, Y.; Qiu, J. MiR-345-3p attenuates apoptosis and inflammation caused by oxidized low-density lipoprotein by targeting TRAF6 via TAK1/p38/NF-kB signaling in endothelial cells. Life Sci. 2020, $241,117142$. [CrossRef]

90. Xu, X.; Zheng, S. MiR-887-3p negatively regulates StARD13 and promotes pancreatic cancer progression. Cancer Manag. Res. 2020, 12, 6137-6147. [CrossRef]

91. Wu, K.; Yu, Z.; Tang, Z.; Wei, W.; Xie, D.; Xie, Y.; Xiao, Q. MiR-877-5p suppresses gastric cancer cell proliferation through targeting FOXM1. Onco. Targets. Ther. 2020, 13, 4731-4742. [CrossRef]

92. Muti, P.; Donzelli, S.; Sacconi, A.; Hossain, A.; Ganci, F.; Frixa, T.; Sieri, S.; Krogh, V.; Berrino, F.; Biagioni, F.; et al. MiRNA-513a-5p inhibits progesterone receptor expression and constitutes a risk factor for breast cancer: The hOrmone and Diet in the ETiology of breast cancer prospective study. Carcinogenesis 2018, 39, 98-108. [CrossRef]

93. Zhu, F.; Li, H.; Ding, F.; Guo, H.; Mou, H.; Ma, J. MiR-422a in gastric cancer cells directly targets CDC40 and modulates cell proliferation. Am. J. Transl. Res. 2020, 12, 4693.

94. Wang, Y.; Yang, L.; Chen, T.; Liu, X.; Guo, Y.; Zhu, Q.; Tong, X.; Yang, W.; Xu, Q.; Huang, D.; et al. A novel lncRNA MCM3AP-AS1 promotes the growth of hepatocellular carcinoma by targeting miR-194-5p/FOXA1 axis. Mol. Cancer 2019, 18, 28. [CrossRef] [PubMed]

95. Zhang, T.; Hu, J.; Wang, X.; Zhao, X.; Li, Z.; Niu, J.; Steer, C.J.; Zheng, G.; Song, G. MicroRNA-378 promotes hepatic inflammation and fibrosis via modulation of the NF-kB-TNF $\alpha$ pathway. J. Hepatol. 2019, 70, 87-96. [CrossRef] [PubMed]

96. Zhao, J.P.; Chen, L.L. Circular rna mat $2 \mathrm{~b}$ induces colorectal cancer proliferation via sponging mir-610, resulting in an increased e2f1 expression. Cancer Manag. Res. 2020, 12, 7107. [CrossRef] [PubMed]

97. Wang, F.; Long, G.; Zhao, C.; Li, H.; Chaugai, S.; Wang, Y.; Chen, C.; Wang, D.W. Atherosclerosis-related circulating miRNAs as novel and sensitive predictors for acute myocardial infarction. PLoS ONE 2014, 9, e105734. [CrossRef]

98. Chen, Z.; Li, Y.; Tan, B.; Li, F.; Zhao, Q.; Fan, L.; Zhang, Z.; Zhao, X.; Liu, Y.; Wang, D. Long Non-coding RNA ASNR Targeting miR-519e-5p Promotes Gastric Cancer Development by Regulating FGFR2. Front. Cell Dev. Biol. 2021, 9, 679176. [CrossRef]

99. Chen, F.; Liu, M.; Yu, Y.; Sun, Y.; Li, J.; Hu, W.; Wang, X.; Tong, D. LINC00958 regulated miR-627-5p/YBX2 axis to facilitate cell proliferation and migration in oral squamous cell carcinoma. Cancer Biol. Ther. 2019, 20, 1270-1280. [CrossRef]

100. Liang, T.; Guo, L.; Liu, C. Genome-wide analysis of mir-548 gene family reveals evolutionary and functional implications. J. Biomed. Biotechnol. 2012, 2012, 679563. [CrossRef]

101. Wang, L.; Li, H. MiR-770-5p facilitates podocyte apoptosis and inflammation in diabetic nephropathy by targeting TIMP3. Biosci. Rep. 2020, 40, BSR20193653. [CrossRef]

102. Li, J.; Wang, L.; He, F.; Li, B.; Han, R. Long noncoding RNA LINC00629 restrains the progression of gastric cancer by upregulating AQP4 through competitively binding to miR-196b-5p. J. Cell. Physiol. 2020, 235, 2973-2985. [CrossRef]

103. Zhu, H.; Hu, Y.; Wang, C.; Zhang, X.; He, D. CircGCN1L1 promotes synoviocyte proliferation and chondrocyte apoptosis by targeting miR-330-3p and TNF- $\alpha$ in TMJ osteoarthritis. Cell Death Dis. 2020, 11, 284. [CrossRef]

104. Liu, T.; Feng, X.; Liao, Y. miR-617 Promotes the Growth of IL-22-Stimulated Keratinocytes Through Regulating FOXO4 Expression. Biochem. Genet. 2021, 59, 547-559. [CrossRef] [PubMed]

105. Chen, S.; Tang, Y.; Liu, Y.; Zhang, P.; Lv, L.; Zhang, X.; Jia, L.; Zhou, Y. Exosomes derived from miR-375-overexpressing human adipose mesenchymal stem cells promote bone regeneration. Cell Prolif. 2019, 52, e12669. [CrossRef] [PubMed]

106. Liu, S.; Gong, Y.; Xu, X.D.; Shen, H.; Gao, S.; Bao, H.D.; Guo, S.B.; Yu, X.F.; Gong, J. MicroRNA-936/ERBB4/Akt axis exhibits anticancer properties of gastric cancer through inhibition of cell proliferation, migration, and invasion. Kaohsiung J. Med. Sci. 2021, 37, 111-120. [CrossRef]

107. Wang, P.; Wang, Z.; Liu, G.; Jin, C.; Zhang, Q.; Man, S.; Wang, Z. MiR-657 promotes macrophage polarization toward M1 by targeting FAM46C in gestational diabetes mellitus. Mediat. Inflamm. 2019, 2019, 4851214. [CrossRef] [PubMed]

108. Garros, R.F.; Paul, R.; Connolly, M.; Lewis, A.; Garfield, B.E.; Natanek, S.A.; Bloch, S.; Mouly, V.; Griffiths, M.J.; Polkey, M.I.; et al. MicroRNA-542 promotes mitochondrial dysfunction and SMAD activity and is elevated in intensive care unit-acquired weakness. Am. J. Respir. Crit. Care Med. 2017, 196, 1422-1433. [CrossRef]

109. Chen, Y.; Yu, H.; Zhu, D.; Liu, P.; Yin, J.; Liu, D.; Zheng, M.; Gao, J.; Zhang, C.; Gao, Y. miR-136-3p targets PTEN to regulate vascularization and bone formation and ameliorates alcohol-induced osteopenia. FASEB J. 2020, 34, 5348-5362. [CrossRef] [PubMed] 
110. Xu, Y. MicroRNA-136-3p inhibits glioma tumorigenesis in vitro and in vivo by targeting KLF7. World J. Surg. Oncol. 2020, 18, 1-10. [CrossRef]

111. Xue, Q.; Yang, D.; Zhang, J.; Gan, P.; Lin, C.; Lu, Y.; Zhang, W.; Zhang, L.; Guang, X. USP7, negatively regulated by miR-409-5p, aggravates hypoxia-induced cardiomyocyte injury. APMIS 2021, 129, 152-162. [CrossRef]

112. Wang, Y.; Lin, W.; Ju, J. MicroRNA-409-5p promotes retinal neovascularization in diabetic retinopathy. Cell Cycle 2020, 19, 1314-1325. [CrossRef]

113. Fan, X.D.; Luo, Y.; Wang, J.; An, N. MiR-154-3p and miR-487-3p synergistically modulate RHOA signaling in the carcinogenesis of thyroid cancer. Biosci. Rep. 2020, 40, BSR20193158. [CrossRef]

114. Ma, J.; Wu, D.; Yi, J.; Yi, Y.; Zhu, X.; Qiu, H.; Kong, R.; Lin, J.; Qian, J.; Deng, Z. MiR-378 promoted cell proliferation and inhibited apoptosis by enhanced stem cell properties in chronic myeloid leukemia K562 cells. Biomed. Pharmacother. 2019, 112, 108623. [CrossRef] [PubMed]

115. Tang, B.; Xuan, L.; Tang, M.; Wang, H.; Zhou, J.; Liu, J.; Wu, S.; Li, M.; Wang, X.; Zhang, H. miR-93-3p alleviates lipopolysaccharideinduced inflammation and apoptosis in H9c2 cardiomyocytes by inhibiting toll-like receptor 4. Pathol. Res. Pract. 2018, 214, 1686-1693. [CrossRef] [PubMed]

116. Jin, W.; Chen, L.; Gao, F.; Yang, M.; Liu, Y.; Wang, B. Down-regulation of miR-556-3p inhibits hemangioma cell proliferation and promotes apoptosis by targeting VEGFC. Cell. Mol. Biol. 2020, 66, 204-207. [CrossRef] [PubMed]

117. Yang, X.; Yang, S.; Song, J.; Yang, W.; Ji, Y.; Zhang, F.; Rao, J. Dysregulation of miR-23b-5p promotes cell proliferation via targeting FOXM1 in hepatocellular carcinoma. Cell Death Discov. 2021, 7, 1-12. [CrossRef] [PubMed]

118. Zhou, R.; Mao, Y.; Xiong, L.; Li, L. Integrated Transcriptome Analysis of microRNA and mRNA in Mouse Skin Derived Precursors (SKPs) and SKP Derived Fibroblast (SFBs) by RNA-Seq. Curr. Genomics 2018, 20, 49-60. [CrossRef] [PubMed]

119. Tang, P. Clinical diagnostic value of circulating serum miR-509-3p in pulmonary arterial hypertension with congenital heart disease. Hell. J. Cardiol. 2020, 61, 26-30. [CrossRef]

120. Stark, M.S.; Bonazzi, V.F.; Boyle, G.M.; Palmer, J.M.; Symmons, J.; Lanagan, C.M.; Schmidt, C.W.; Herington, A.C.; Ballotti, R.; Pollock, P.M.; et al. miR-514a regulates the tumour suppressor NF1 and modulates BRAFi sensitivity in melanoma. Oncotarget 2015, 6, 17753. [CrossRef]

121. Wang, Y.; Zhang, K.; Yuan, X.; Xu, N.; Zhao, S.; Hou, L.; Yang, L.; Zhang, N. MiR-431-5p regulates cell proliferation and apoptosis in fibroblast-like synoviocytes in rheumatoid arthritis by targeting XIAP. Arthritis Res. Ther. 2020, 22, 231. [CrossRef]

122. Wang, Y.; Lei, X.; Gao, C.; Xue, Y.; Li, X.; Wang, H.; Feng, Y. MiR-506-3p suppresses the proliferation of ovarian cancer cells by negatively regulating the expression of MTMR6. J. Biosci. 2019, 44, 126. [CrossRef]

123. Zhu, B.; Tian, T.; Zhao, M. MiR-645 promotes proliferation and migration of non-small cell lung cancer cells by targeting TP53I11. Eur. Rev. Med. Pharmacol. Sci. 2020, 24, 6150-6156. [CrossRef]

124. Zhang, Y.; Wang, Y.; Wei, Y.; Li, M.; Yu, S.; Ye, M.; Zhang, H.; Chen, S.; Liu, W.; Zhang, J. MiR-129-3p promotes docetaxel resistance of breast cancer cells via CP110 inhibition. Sci. Rep. 2015, 5, 15424. [CrossRef] [PubMed]

125. Huang, Y.; Jiang, L.; Wei, G. Circ_0006168 promotes the migration, invasion and proliferation of esophageal squamous cell carcinoma cells via mir-516b-5p-dependent regulation of xbp1. Onco. Targets. Ther. 2021, 14, 475-2488. [CrossRef] [PubMed]

126. Kong, M.; Han, Y.; Zhao, Y.; Zhang, H. miR-512-3p Overcomes Resistance to Cisplatin in Retinoblastoma by Promoting Apoptosis Induced by Endoplasmic Reticulum Stress. Med. Sci. Monit. 2020, 26, 923817. [CrossRef] [PubMed]

127. Wang, H.; Guo, Y.; Mi, N.; Zhou, L. miR-101-3p and miR-199b-5p promote cell apoptosis in oral cancer by targeting BICC1. Mol. Cell. Probes 2020, 52, 101567. [CrossRef]

128. Liao, Z.J.; Zheng, Q.; Wei, T.; Zhang, Y.B.; Ma, J.Q.; Zhao, Z.; Sun, H.F.; Nan, K.J. MicroRNA-561 Affects Proliferation and Cell Cycle Transition through PTEN/AKT Signaling Pathway by Targeting P-REX2a in NSCLC. Oncol. Res. 2020, 28, 147-159. [CrossRef]

129. He, Q.; Liu, N.; Hu, F.; Shi, Q.; Pi, X.; Chen, H.; Li, J.; Zhang, B. Circ_0061012 contributes to IL-22-induced proliferation, migration and invasion in keratinocytes through miR-194-5p/GAB1 axis in psoriasis. Biosci. Rep. 2021, 4, BSR20203130. [CrossRef]

130. Wang, Y.P.; Li, H.Q.; Chen, J.X.; Kong, F.G.; Mo, Z.H.; Wang, J.Z.; Huang, K.M.; Li, X.N.; Yan, Y. Overexpression of XIST facilitates cell proliferation, invasion and suppresses cell apoptosis by reducing radio-sensitivity of glioma cells via miR-329-3p/CREB1 axis. Eur. Rev. Med. Pharmacol. Sci. 2020, 24, 3190-3203. [CrossRef]

131. Wang, Y.F.; Lian, X.L.; Zhong, J.Y.; Su, S.X.; Xu, Y.F.; Xie, X.F.; Wang, Z.P.; Li, W.; Zhang, L.; Che, D.; et al. Serum exosomal microRNA let-7i-3p as candidate diagnostic biomarker for Kawasaki disease patients with coronary artery aneurysm. IUBMB Life 2019, 71, 891-900. [CrossRef]

132. Liu, Z.; Dou, C.; Yao, B.; Xu, M.; Ding, L.; Wang, Y.; Jia, Y.; Li, Q.; Zhang, H.; Tu, K.; et al. Methylation-mediated repression of microRNA-129-2 suppresses cell aggressiveness by inhibiting high mobility group box 1 in human hepatocellular carcinoma. Oncotarget 2016, 7, 36909-36923. [CrossRef]

133. Zhao, G.; Wang, T.; Huang, Q.K.; Pu, M.; Sun, W.; Zhang, Z.C.; Ling, R.; Tao, K.S. MicroRNA-548a-5p promotes proliferation and inhibits apoptosis in hepatocellular carcinoma cells by targeting Tg737. World J. Gastroenterol. 2016, 22, 5364-5373. [CrossRef]

134. Jiang, Y.; Wang, N.; Yin, D.; Li, Y.K.; Guo, L.; Shi, L.P.; Huang, X. Changes in the Expression of Serum MiR-887-5p in Patients with Endometrial Cancer. Int. J. Gynecol. Cancer 2016, 26, 1143-1147. [CrossRef] [PubMed]

135. Moura, S.R.; Bras, J.P.; Freitas, J.; Osório, H.; Barbosa, M.A.; Santos, S.G.; Almeida, M.I. miR-99a in bone homeostasis: Regulating osteogenic lineage commitment and osteoclast differentiation. Bone 2020, 134, 115303. [CrossRef] [PubMed] 
136. Fan, Y.; Hao, J.; Cen, X.; Song, K.; Yang, C.; Xiao, S.; Cheng, S. Downregulation of miR-487a-3p suppresses the progression of non-small cell lung cancer via targeting Smad7. Drug Dev. Res. 2021. [CrossRef]

137. Liu, W.; Yang, Y.J.; An, Q. LINC00963 promotes ovarian cancer proliferation, migration and EMT via the miR-378g/CHI3L1 axis. Cancer Manag. Res. 2020, 12, 463-473. [CrossRef] [PubMed]

138. Li, F.; Liu, H.; Cheng, Y.; Yang, J.; Liu, Y.; Wang, Y.; Yang, Z.; Shi, C.; Xu, Y. Association of variants in microRNA with Parkinson's disease in Chinese Han population. Neurol. Sci. 2018, 39, 353-357. [CrossRef]

139. Dong, L.; Zheng, Y.; Gao, L.; Luo, X. lncRNA NEAT1 prompts autophagy and apoptosis in MPTP-induced Parkinson's disease by impairing miR-374c-5p. Acta Biochim. Biophys. Sin. 2021, 53, 870-882. [CrossRef]

140. Zhu, M.; Zhang, N.; He, S.; Yan, R.; Zhang, J. MicroRNA-106a functions as an oncogene in human gastric cancer and contributes to proliferation and metastasis in vitro and in vivo. Clin. Exp. Metastasis 2016, 3, 509-519. [CrossRef]

141. Long, C.Y.; Xiao, Y.X.; Li, S.Y.; Tang, X.B.; Yuan, Z.W.; Bai, Y.Z. Upregulation of miR-92a-2-5p potentially contribute to anorectal malformations by inhibiting proliferation and enhancing apoptosis via PRKCA/ $\beta$-catenin. Biomed. Pharmacother. 2020, $127,110117$. [CrossRef]

142. Zhu, L.M.; Li, N. Downregulation of long noncoding RNA TUSC7 promoted cell growth, invasion and migration through sponging with miR-616-5p/GSK3 $\beta$ pathway in ovarian cancer. Eur. Rev. Med. Pharmacol. Sci. 2020, 24, 7253-7265. [CrossRef]

143. Fu, L.; Li, Z.; Zhu, J.; Wang, P.; Fan, G.; Dai, Y.; Zheng, Z.; Liu, Y. Serum expression levels of microRNA-382-3p, -598-3p, -1246 and -184 in breast cancer patients. Oncol. Lett. 2016, 12, 269-274. [CrossRef]

144. Li, G.; Xu, Y.; Wang, S.; Yan, W.; Zhao, Q.; Guo, J. MiR-873-5p inhibits cell migration, invasion and epithelial-mesenchymal transition in colorectal cancer via targeting ZEB1. Pathol. Res. Pract. 2019, 215, 34-39. [CrossRef] [PubMed]

145. Liu, Z.; Su, D.; Qi, X.; Ma, J. MiR-500a-5p promotes glioblastoma cell proliferation, migration and invasion by targeting chromodomain helicase DNA binding protein 5. Mol. Med. Rep. 2018, 18, 2689-2696. [CrossRef] [PubMed]

146. Liu, Z.; He, C.; Qu, Y.; Chen, X.; Zhu, H.; Xiang, B. MiR-659-3p regulates the progression of chronic myeloid leukemia by targeting SPHK1. Int. J. Clin. Exp. Pathol. 2018, 11, 2470.

147. Lin, Q.; Jia, Y.; Zhang, D.; Jin, H. NCK1-AS1 promotes the progression of melanoma by accelerating cell proliferation and migration via targeting miR-526b-5p/ADAM15 axis. Cancer Cell Int. 2021, 21, 1-10. [CrossRef]

148. Zhu, F.; Li, Q.; Li, J.; Li, B.; Li, D. Long noncoding Mirt2 reduces apoptosis to alleviate myocardial infarction through regulation of the miR-764/PDK1 axis. Lab. Investig. 2021, 101, 165-176. [CrossRef] [PubMed]

149. Zhao, S.; Mi, Y.; Guan, B.; Zheng, B.; Wei, P.; Gu, Y.; Zhang, Z.; Cai, S.; Xu, Y.; Li, X.; et al. Tumor-derived exosomal miR-934 induces macrophage M2 polarization to promote liver metastasis of colorectal cancer. J. Hematol. Oncol. 2020, 13, 156. [CrossRef]

150. Ye, X.Y.; Xu, L.; Lu, S.; Chen, Z.W. Mir-516a-5p inhibits the proliferation of non-small cell lung cancer by targeting hist3h2a. Int. J. Immunopathol. Pharmacol. 2019, 33, 2058738419841481. [CrossRef] [PubMed]

151. Yuan, X.; Ma, R.; Yang, S.; Jiang, L.; Wang, Z.; Zhu, Z.; Li, H. miR-520g and miR-520h overcome bortezomib resistance in multiple myeloma via suppressing APE1. Cell Cycle 2019, 18, 1660-1669. [CrossRef]

152. Wang, J.; Wang, H.; Liu, A.; Fang, C.; Hao, J.; Wang, Z. Lactate dehydrogenase A negatively regulated by miRNAs promotes aerobic glycolysis and is increased in colorectal cancer. Oncotarget 2015, 6, 19465. [CrossRef]

153. Su, X.; Gao, C.; Feng, X.; Jiang, M. miR-613 suppresses migration and invasion in esophageal squamous cell carcinoma via the targeting of G6PD. Exp. Ther. Med. 2020, 19, 3081-3089. [CrossRef]

154. Wang, M.; Zhao, H.Y.; Zhang, J.L.; Wan, D.M.; Li, Y.M.; Jiang, Z.X. Dysregulation of LncRNA ANRIL mediated by miR-411-3p inhibits the malignant proliferation and tumor stem cell like property of multiple myeloma via hypoxia-inducible factor $1 \alpha$. Exp. Cell Res. 2020, 396, 112280. [CrossRef] [PubMed]

155. Hou, J.; Li, A.L.; Xiong, W.Q.; Chen, R. Hsa Circ 001839 Promoted Inflammation in Renal Ischemia-Reperfusion Injury through NLRP3 by miR-432-3p. Nephron 2021, 145, 540-552. [CrossRef] [PubMed]

156. Fan, R.F.; Cao, C.Y.; Chen, M.H.; Shi, Q.X.; Xu, S.W. Gga-let-7f-3p promotes apoptosis in selenium deficiency-induced skeletal muscle by targeting selenoprotein K. Metallomics 2018, 10, 941-952. [CrossRef] [PubMed]

157. Zhang, B. Guizhi Fuling pills inhibit the proliferation, migration and invasion of human cutaneous malignant melanoma cells by regulating the molecular axis of LncRNA TPT1-AS1/miR-671-5p. Cell. Mol. Biol. 2020, 66, 148-154. [CrossRef]

158. Li, Y.; Kuscu, C.; Banach, A.; Zhang, Q.; Pulkoski-Gross, A.; Kim, D.; Liu, J.; Roth, E.; Li, E.; Shroyer, K.R.; et al. miR-181a$5 p$ inhibits cancer cell migration and angiogenesis via downregulation of matrix metalloproteinase-14. Cancer Res. 2015, 75, 2674-2685. [CrossRef] [PubMed]

159. Baker, M.A.; Wang, F.; Liu, Y.; Kriegel, A.J.; Geurts, A.M.; Usa, K.; Xue, H.; Wang, D.; Kong, Y.; Liang, M. MiR-192-5p in the Kidney Protects Against the Development of Hypertension. Hypertension 2019, 73, 399-406. [CrossRef]

160. Zhang, H.; Zhang, Z.; Gao, L.; Qiao, Z.; Yu, M.; Yu, B.; Yang, T. miR-1-3p suppresses proliferation of hepatocellular carcinoma through targeting SOX9. Onco. Targets. Ther. 2019, 12, 2149-2157. [CrossRef]

161. Wang, Y.; Zhang, Q. Long Noncoding RNA MALAT1 Knockdown Inhibits Proliferation, Migration, and Invasion and Promotes Apoptosis in Non-Small-Cell Lung Cancer Cells Through Regulating miR-515-3p/TRIM65 Axis. Cancer Biother. Radiopharm. 2020. [CrossRef]

162. Liu, L.; Zhang, H.; Mao, H.; Li, X.; Hu, Y. Exosomal miR-320d derived from adipose tissue-derived MSCs inhibits apoptosis in cardiomyocytes with atrial fibrillation (AF). Artif. Cells Nanomed. Biotechnol. 2019, 47, 3976-3984. [CrossRef] 
163. Peng, X.; Wu, M.; Liu, W.; Guo, C.; Zhan, L.; Zhan, X. MiR-502-5p inhibits the proliferation, migration and invasion of gastric cancer cells by targeting SP1. Oncol. Lett. 2020, 20, 2757-2762. [CrossRef]

164. Wu, X.; Chen, B.; Shi, H.; Zhou, J.; Zhou, F.; Cao, J.; Sun, X. miR-758-3p suppresses human bladder cancer cell proliferation, migration and invasion by targeting NOTCH2. Exp. Ther. Med. 2019, 17, 4273-4278. [CrossRef]

165. Pourhanifeh, M.H.; Mahjoubin-Tehran, M.; Karimzadeh, M.R.; Mirzaei, H.R.; Razavi, Z.S.; Sahebkar, A.; Hosseini, N.; Mirzaei, H.; Hamblin, M.R. Autophagy in cancers including brain tumors: Role of MicroRNAs. Cell Commun. Signal. 2020, 18, 88. [CrossRef] [PubMed]

166. Xu, J.; Lei, S.; Sun, S.; Zhang, W.; Zhu, F.; Yang, H.; Xu, Q.; Zhang, B.; Li, H.; Zhu, M.; et al. Mir-324-3p regulates fibroblast proliferation via targeting tgf- $\beta 1$ in atrial fibrillation. Int. Heart J. 2020, 61, 20-423. [CrossRef] [PubMed]

167. Kordaß, T.; Weber, C.E.M.; Eisel, D.; Pane, A.A.; Osen, W.; Eichmüller, S.B. miR-193b and miR-30c-1* inhibit, whereas miR-576-5p enhances melanoma cell invasion in vitro. Oncotarget 2018, 9, 32507-32522. [CrossRef] [PubMed]

168. Li, J.; Shao, W.; Zhao, J. MiR-520a-3p inhibits malignant progression of epithelial ovarian cancer by targeting SUV39H1 expression. Hum. Cell 2021, 34, 570-578. [CrossRef]

169. Fang, Y.; Gu, X.; Li, Z.; Xiang, J.; Chen, Z. miR-449b inhibits the proliferation of SW1116 colon cancer stem cells through downregulation of CCND1 and E2F3 expression. Oncol. Rep. 2013, 30, 399-506. [CrossRef] [PubMed]

170. Díaz-Martínez, M.; Benito-Jardon, L.; Alonso, L.; Koetz-Ploch, L.; Hernando, E.; Teixido, J. miR-204-5p and miR-211-5p contribute to BRAF inhibitor resistance in melanoma. Cancer Res. 2018, 78, 1017-1030. [CrossRef] [PubMed]

171. Du, L.; Xu, Z.; Wang, X.; Liu, F. Integrated bioinformatics analysis identifies microRNA-376a-3p as a new microRNA biomarker in patient with coronary artery disease. Am. J. Transl. Res. 2020, 12, 633-648.

172. Han, X.; Du, C.; Chen, Y.; Zhong, X.; Wang, F.; Wang, J.; Liu, C.; Li, M.; Chen, S.; Li, B. Overexpression of miR-939-3p predicts poor prognosis and promotes progression in lung cancer. Cancer Biomark. 2019, 25, 335-342. [CrossRef]

173. Xu, M.; Sun, J.; Yu, Y.; Pang, Q.; Lin, X.; Barakat, M.; Lei, R.; Xu, J. TM4SF1 involves in miR-1-3p/miR-214-5p-mediated inhibition of the migration and proliferation in keloid by regulating AKT/ERK signaling. Life Sci. 2020, 254, 117746. [CrossRef]

174. Van Solingen, C.; Oldebeken, S.R.; Salerno, A.G.; Wanschel, A.C.B.A.; Moore, K.J. High-Throughput Screening Identifies MicroRNAs Regulating Human PCSK9 and Hepatic Low-Density Lipoprotein Receptor Expression. Front. Cardiovasc. Med. 2021, 8, 701. [CrossRef] [PubMed]

175. Sassi, Y.; Avramopoulos, P.; Ramanujam, D.; Grüter, L.; Werfel, S.; Giosele, S.; Brunner, A.D.; Esfandyari, D.; Papadopoulou, A.S.; De Strooper, B.; et al. Cardiac myocyte miR-29 promotes pathological remodeling of the heart by activating Wnt signaling. Nat. Commun. 2017, 8, 1614. [CrossRef] [PubMed]

176. Miao, L.J.; Huang, S.F.; Sun, Z.T.; Gao, Z.Y.; Zhang, R.X.; Liu, Y.; Wang, J. MiR-449c targets c-Myc and inhibits NSCLC cell progression. FEBS Lett. 2013, 587, 1359-1365. [CrossRef] [PubMed]

177. Deng, Z.H.; Yu, G.S.; Deng, K.L.; Feng, Z.H.; Huang, Q.; Pan, B.; Deng, J.Z. Hsa_circ_0088233 Alleviates Proliferation, Migration, and Invasion of Prostate Cancer by Targeting hsa-miR-185-3p. Front. Cell Dev. Biol. 2020, 8, 528155. [CrossRef]

178. Ye, W.; Ma, J.; Wang, F.; Wu, T.; He, M.; Li, J.; Pei, R.; Zhang, L.; Wang, Y.; Zhou, J. LncRNA MALAT 1 Regulates miR-144-3p to Facilitate Epithelial-Mesenchymal Transition of Lens Epithelial Cells via the ROS/NRF2/Notch1/Snail Pathway. Oxid. Med. Cell. Longev. 2020, 2020, 8184314. [CrossRef]

179. Watanabe, K.; Yamaji, R.; Ohtsuki, T. MicroRNA-664a-5p promotes neuronal differentiation of SH-SY5Y cells. Genes Cells 2018, 23, 225-233. [CrossRef]

180. Huang, D.; Liu, Y.; Gao, L.; Wei, X.; Xu, Y.; Cai, R.; Su, Q. MiR-32-3p Regulates Myocardial Injury Induced by Microembolism and Microvascular Obstruction by Targeting RNF13 to Regulate the Stability of Atherosclerotic Plaques. J. Cardiovasc. Transl. Res. 2021, 1-24. [CrossRef]

181. Wang, G.; Liu, L.; Zhang, J.; Huang, C.; Chen, Y.; Bai, W.; Wang, Y.; Zhao, K.; Li, S. Lncrna hcg11 suppresses cell proliferation and promotes apoptosis via sponging mir-224-3p in non-small-cell lung cancer cells. Onco. Targets. Ther. 2020, 3, 6553-6563. [CrossRef]

182. Pan, X.; He, Y.; Chen, Z.; Yan, G.; Ma, G. Circulating miR-130 is a potential bio signature for early prognosis of acute myocardial infarction. I. Thorac. Dis. 2020, 12, 7320-7325. [CrossRef]

183. Krist, B.; Florczyk, U.; Pietraszek-Gremplewicz, K.; Józkowicz, A.; Dulak, J. The role of miR-378a in metabolism, angiogenesis, and muscle biology. Int. J. Endocrinol. 2015, 2015, 281756. [CrossRef]

184. Kurowska, W.; Kuca-Warnawin, E.; Radzikowska, A.; Jakubaszek, M.; Maślińska, M.; Kwiatkowska, B.; Maśliński, W. Monocyterelated biomarkers of rheumatoid arthritis development in undifferentiated arthritis patients-A pilot study. Reumatologia 2018, 56, 10-16. [CrossRef] [PubMed]

185. Ma, H.; Huang, C.; Huang, Q.; Li, G.; Li, J.; Huang, B.; Zhong, Q.; Cao, C. Circular RNA circ_0014717 Suppresses Hepatocellular Carcinoma Tumorigenesis Through Regulating miR-668-3p/BTG2 Axis. Front. Oncol. 2021, 10, 3013. [CrossRef] [PubMed]

186. Jiang, M.; Yin, Y.; Xie, L.; He, H. Plasma miR-18 screens acute myocardial infarction from healthy controls by targeting hypoxia inducible factor $1 \alpha$. Clin. Lab. 2018, 64, 1207-1212. [CrossRef]

187. Lupini, L.; Pepe, F.; Ferracin, M.; Braconi, C.; Callegari, E.; Pagotto, S.; Spizzo, R.; Zagatti, B.; Lanuti, P.; Fornari, F.; et al Over-expression of the miR-483-3p overcomes the miR-145/TP53 pro-apoptotic loop in hepatocellular carcinoma. Oncotarget 2016, 7, 31361. [CrossRef] [PubMed]

188. Pan, Y.; Qin, J.; Sun, H.; Xu, T.; Wang, S.; He, B. MiR-485-5p as a potential biomarker and tumor suppressor in human colorectal cancer. Biomark. Med. 2020, 14, 239-248. [CrossRef] 
189. Carlomosti, F.; D’Agostino, M.; Beji, S.; Torcinaro, A.; Rizzi, R.; Zaccagnini, G.; Maimone, B.; Di Stefano, V.; De Santa, F.; Cordisco, S.; et al. Oxidative Stress-Induced miR-200c Disrupts the Regulatory Loop among SIRT1, FOXO1, and eNOS. Antioxid. Redox Signal. 2017, 27, 328-344. [CrossRef]

190. Li, S.N.; Li, P.; Liu, W.H.; Shang, J.J.; Qiu, S.L.; Zhou, M.X.; Liu, H.X. Danhong injection enhances angiogenesis after myocardial infarction by activating MiR-126/ERK/VEGF pathway. Biomed. Pharmacother. 2019, 120, 109538. [CrossRef]

191. Tsai, M.M.; Huang, H.W.; Wang, C.S.; Lee, K.F.; Tsai, C.Y.; Lu, P.H.; Chi, H.C.; Lin, Y.H.; Kuo, L.M.; Lin, K.H. MicroRNA-26b inhibits tumor metastasis by targeting the KPNA2/c-jun pathway in human gastric cancer. Oncotarget 2016, 7, 39511-39526. [CrossRef]

192. Skrzypek, K.; Tertil, M.; Golda, S.; Ciesla, M.; Weglarczyk, K.; Collet, G.; Guichard, A.; Kozakowska, M.; Boczkowski, J.; Was, H.; et al. Interplay between heme oxygenase- 1 and miR-378 affects non-small cell lung carcinoma growth, vascularization, and metastasis. Antioxid. Redox Signal. 2013, 19, 644-660. [CrossRef]

193. Wu, M.; Li, X.; Liu, Q.; Xie, Y.; Yuan, J.; Wanggou, S. miR-526b-3p serves as a prognostic factor and regulates the proliferation, invasion, and migration of glioma through targeting WEEI. Cancer Manag. Res. 2019, 11, 3099-3110. [CrossRef]

194. Wang, Y.N.; Xu, F.; Zhang, P.; Wang, P.; Wei, Y.N.; Wu, C.; Cheng, S.J. MicroRNA-575 regulates development of gastric cancer by targeting PTEN. Biomed. Pharmacother. 2019, 113, 108716. [CrossRef] [PubMed]

195. Liang, C.; Xu, Y.; Ge, H.; Xing, B.; Li, G.; Li, G.; Wu, J. MiR-564 inhibits hepatocellular carcinoma cell proliferation and invasion by targeting the GRB2-ERK1/2-AKT axis. Oncotarget 2017, 8, 107543-107557. [CrossRef] [PubMed]

196. Li, S.; Xu, Y.N.; Niu, X.; Li, Z.; Wang, J.F. miR-513a-5p targets Bcl-2 to promote dichlorvos induced apoptosis in HK-2 cells. Biomed. Pharmacother. 2018, 108, 876-882. [CrossRef] [PubMed]

197. Shu, W.; Zhang, Y.; Zhang, C.; You, Q.; Zhou, H.; Wen, S. Triclosan inhibits the activation of human periodontal ligament fibroblasts induced by lipopolysaccharide from Porphyromonas gingivalis. J. Biomed. Res. 2021, 35, 206. [CrossRef]

198. Wang, M.; Qiu, R.; Gong, Z.; Zhao, X.; Wang, T.; Zhou, L.; Lu, W.; Shen, B.; Zhu, W.; Xu, W. miR-188-5p emerges as an oncomiRNA to promote gastric cancer cell proliferation and migration via upregulation of SALL4. J. Cell. Biochem. 2019, 120, 15027-15037. [CrossRef] [PubMed]

199. Zhang, X.; Li, M.; Sun, G.; Bai, Y.; Lv, D.; Liu, C. MiR-563 restrains cell proliferation via targeting LIN28B in human lung cancer. Thorac. Cancer 2020, 11, 55-61. [CrossRef]

200. Zhang, W.; Xu, J.; Wang, K.; Tang, X.; He, J. MIR-139-3p suppresses the invasion and migration properties of breast cancer cells by targeting RAB1A. Oncol. Rep. 2019, 42, 1699-1708. [CrossRef] [PubMed]

201. Pan, Y.; Hui, X.; Chong Hoo, R.L.; Ye, D.; Cheung Chan, C.Y.; Feng, T.; Wang, Y.; Ling Lam, K.S.; Xu, A. Adipocyte-secreted exosomal microRNA-34a inhibits M2 macrophage polarization to promote obesity-induced adipose inflammation. J. Clin. Investig. 2019, 129, 834-849. [CrossRef]

202. Liu, X.; Feng, J.; Tang, L.; Liao, L.; Xu, Q.; Zhu, S. The regulation and function of mir-21-foxo3a-mir-34b/c signaling in breast cancer. Int. J. Mol. Sci. 2015, 16, 3148-3162. [CrossRef]

203. Luo, X.; Zhang, X.; Peng, J.; Chen, Y.; Zhao, W.; Jiang, X.; Su, L.; Xie, M.; Lin, B. miR-371b-5p promotes cell proliferation, migration and invasion in non-small cell lung cancer via SCAI. Biosci. Rep. 2020, 40, BSR290200163. [CrossRef]

204. Zhu, G.; Zhang, W.; Liu, Y.; Wang, S. MiR-371b-5p inhibits endothelial cell apoptosis in monocrotaline-induced pulmonary arterial hypertension via PTEN/PI3K/Akt signaling pathways. Mol. Med. Rep. 2018, 8, 5489-5501. [CrossRef] [PubMed]

205. Li, D.; Chen, L.; Zhao, W.; Hao, J.; An, R. MicroRNA-let-7f-1 is induced by lycopene and inhibits cell proliferation and triggers apoptosis in prostate cancer. Mol. Med. Rep. 2016, 13, 2708-2714. [CrossRef] [PubMed]

206. Qiu, J.; Hao, Y.; Huang, S.; Ma, Y.; Li, X.; Li, D.; Mao, Y. MIR-557 works as a tumor suppressor in human lung cancers by negatively regulating LEF1 expression. Tumor Biol. 2017, 39, 1010428317709467. [CrossRef] [PubMed]

207. Cui, J.; Qi, S.; Liao, R.; Su, D.; Wang, Y.; Xue, S. MiR-574-5p promotes the differentiation of human cardiac fibroblasts via regulating ARID3A. Biochem. Biophys. Res. Commun. 2020, 521, 427-433. [CrossRef]

208. Wang, X.; Shi, J.; Niu, Z.; Wang, J.; Zhang, W. MiR-216a-3p regulates the proliferation, apoptosis, migration, and invasion of lung cancer cells via targeting COPB2. Biosci. Biotechnol. Biochem. 2020, 84, 2014-2027. [CrossRef]

209. Tong, F.; Ying, Y.; Pan, H.; Zhao, W.; Li, H.; Zhan, X. Microrna-466 (Mir-466) functions as a tumor suppressor and prognostic factor in colorectal cancer (CRC). Bosn. J. Basic Med. Sci. 2018, 18, 252-259. [CrossRef]

210. He, N.; Liu, L.; Ding, J.; Sun, Y.; Xing, H.; Wang, S. MiR-222-3p ameliorates glucocorticoid-induced inhibition of airway epithelial cell repair through down-regulating GILZ expression. J. Recept. Signal Transduct. 2020, 40, 301-312. [CrossRef]

211. Yang, L.; Liu, Z.M.; Rao, Y.W.; Cui, S.Q.; Wang, H.; Jia, X.J. Downregulation of microRNA-586 Inhibits Proliferation, Invasion and Metastasis and Promotes Apoptosis in Human Osteosarcoma U2-OS Cell Line. Cytogenet. Genome Res. 2015, 146, 268-278. [CrossRef]

212. Ramanathan, S.; Shenoda, B.B.; Lin, Z.; Alexander, G.M.; Huppert, A.; Sacan, A.; Ajit, S.K. Inflammation potentiates miR-939 expression and packaging into small extracellular vesicles. J. Extracell. Vesicles 2019, 8, 1650595. [CrossRef]

213. Lin, L.; Wang, Y. MiR-548b-3p regulates proliferation, apoptosis, and mitochondrial function by targeting CIP2A in hepatocellular carcinoma. Biomed Res. Int. 2018, 2018, 7385426. [CrossRef] 
214. Herrera-Van Oostdam, A.S.; Toro-Ortíz, J.C.; López, J.A.; Noyola, D.E.; García-López, D.A.; Durán-Figueroa, N.V.; MartínezMartínez, E.; Portales-Pérez, D.P.; Salgado-Bustamante, M.; López-Hernández, Y. Placental exosomes isolated from urine of patients with gestational diabetes exhibit a differential profile expression of microRNAs across gestation. Int. J. Mol. Med. 2020, 46, 546-560. [CrossRef] [PubMed]

215. Mei, L.; Yan, H.; Wang, S.; Guo, C.; Zheng, X.; Yan, B.; Zhao, J.; Yang, A. Upregulation of miR-630 Induced by Oxidative Damage Resists Cell Migration Through Targeting ALCAM in Human Lens Epithelium Cells. Curr. Eye Res. 2020, 45, 153-161. [CrossRef] [PubMed]

216. Yanaka, Y.; Muramatsu, T.; Uetake, H.; Kozaki, K.I.; Inazawa, J. miR-544a induces epithelial-mesenchymal transition through the activation of WNT signaling pathway in gastric cancer. Carcinogenesis 2015, 36, 1363-1371. [CrossRef] [PubMed]

217. Lin, Y.X.; Wu, X.B.; Zheng, C.W.; Zhang, Q.L.; Zhang, G.Q.; Chen, K.; Zhan, Q.; An, F.M. Mechanistic Investigation on the Regulation of FABP1 by the IL-6/miR-603 Signaling in the Pathogenesis of Hepatocellular Carcinoma. Biomed Res. Int. 2021, 2021, 8579658. [CrossRef]

218. Cai, W.; Xu, Y.; Yin, J.; Zuo, W.; Su, Z. miR-552-5p facilitates osteosarcoma cell proliferation and metastasis by targeting WIF1. Exp. Ther. Med. 2019, 17, 3781-3788. [CrossRef]

219. Chen, Y.; Lei, Y.; Lin, J.; Huang, Y.; Zhang, J.; Chen, K.; Sun, S.; Lin, X. The Linc01260 functions as a tumor suppressor via the miR-562/CYLD/NF-кB pathway in non-small cell lung cancer. Onco. Targets. Ther. 2020, 13, 10707-10719. [CrossRef] [PubMed]

220. Christofides, A.; Papagregoriou, G.; Dweep, H.; Makrides, N.; Gretz, N.; Felekkis, K.; Deltas, C. Evidence for miR-548c-5p regulation of FOXC2 transcription through a distal genomic target site in human podocytes. Cell. Mol. Life Sci. 2020, 77, 2441-2459. [CrossRef]

221. Kijpaisalratana, N.; Nimsamer, P.; Khamwut, A.; Payungporn, S.; Pisitkun, T.; Chutinet, A.; Utoomprurkporn, N.; Kerr, S.J.; Vongvasinkul, P.; Suwanwela, N.C. Serum miRNA125a-5p, miR-125b-5p, and miR-433-5p as biomarkers to differentiate between posterior circulation stroke and peripheral vertigo. BMC Neurol. 2020, 20, 372. [CrossRef]

222. Mao, Q.; Liang, X.L.; Zhang, C.L.; Pang, Y.H.; Lu, Y.X. LncRNA KLF3-AS1 in human mesenchymal stem cell-derived exosomes ameliorates pyroptosis of cardiomyocytes and myocardial infarction through miR-138-5p/Sirt1 axis. Stem Cell Res. Ther. 2019, 10, 393. [CrossRef]

223. Liu, F.; Yu, X.; Huang, H.; Chen, X.; Wang, J.; Zhang, X.; Lin, Q. Upregulation of microRNA-450 inhibits the progression of lung cancer in vitro and in vivo by targeting interferon regulatory factor 2. Int. J. Mol. Med. 2016, 38, 283-290. [CrossRef]

224. Luo, Y.; Liu, W.; Tang, P.; Jiang, D.; Gu, C.; Huang, Y.; Gong, F.; Rong, Y.; Qian, D.; Chen, J.; et al. MiR-624-5p promoted tumorigenesis and metastasis by suppressing hippo signaling through targeting PTPRB in osteosarcoma cells. J. Exp. Clin. Cancer Res. 2019, 38, 488. [CrossRef] [PubMed]

225. Liang, Y.; Song, X.; Li, Y.; Ma, T.; Su, P.; Guo, R.; Chen, B.; Zhang, H.; Sang, Y.; Liu, Y.; et al. Targeting the circBMPR2/miR553/USP4 Axis as a Potent Therapeutic Approach for Breast Cancer. Mol. Ther. Nucleic Acids 2019, 17, 347-361. [CrossRef] [PubMed]

226. Rongna, A.; Yu, P.; Hao, S.; Li, Y. MiR-876-5p suppresses cell proliferation by targeting Angiopoietin-1 in the psoriasis. Biomed. Pharmacother. 2018, 103, 1163-1169. [CrossRef]

227. Pei, X.; Li, Y.; Zhu, L.; Zhou, Z. Astrocyte-derived exosomes transfer miR-190b to inhibit oxygen and glucose deprivation-induced autophagy and neuronal apoptosis. Cell Cycle 2020, 19, 906-917. [CrossRef] [PubMed]

228. Xie, Q.; Li, F.; Shen, K.; Luo, C.; Song, G. LOXL1-AS1/miR-515-5p/STAT3 Positive Feedback Loop Facilitates Cell Proliferation and Migration in Atherosclerosis. J. Cardiovasc. Pharmacol. 2020, 76, 151-158. [CrossRef] [PubMed]

229. He, X.; Ji, J.; Wang, T.; Wang, M.B.; Chen, X.L. Upregulation of Circulating miR-195-3p in Heart Failure. Cardiology 2017, 138, 107-114. [CrossRef] [PubMed]

230. Li, C.; Han, H.; Li, X.; Wu, J.; Li, X.; Niu, H.; Li, W. Analysis of lncRNA, miRNA, and mRNA Expression Profiling in Type i IFN and Type II IFN Overexpressed in Porcine Alveolar Macrophages. Int. J. Genomics 2021, 2021, 6666160. [CrossRef] [PubMed]

231. Zhang, X.; Gu, H.; Wang, L.; Huang, F.; Cai, J. MiR-885-3p is down-regulated in peripheral blood mononuclear cells from T1D patients and regulates the inflammatory response via targeting TLR4/NF-kB signaling. J. Gene Med. 2020, 22, 3145. [CrossRef]

232. Liao, C.H.; Liu, Y.; Wu, Y.F.; Zhu, S.W.; Cai, R.Y.; Zhou, L.; Yin, X.M. microRNA-329 suppresses epithelial-to-mesenchymal transition and lymph node metastasis in bile duct cancer by inhibiting laminin subunit beta 3. J. Cell. Physiol. 2019, 234, 17786-17799. [CrossRef]

233. Wang, W.; Zhao, E.; Yu, Y.; Geng, B.; Zhang, W.; Li, X. MiR-216a exerts tumor-suppressing functions in renal cell carcinoma by targeting TLR4. Am. J. Cancer Res. 2018, 8, 476-488.

234. Goodwin, A.J.; Li, P.; Halushka, P.V.; Cook, J.A.; Sumal, A.S.; Fan, H. Circulating miRNA 887 is differentially expressed in ARDS and modulates endothelial function. Am. J. Physiol. Lung Cell. Mol. Physiol. 2020, 318, L1261-L1269. [CrossRef] [PubMed]

235. Guo, W.; Li, W.; Yuan, L.; Mei, X.; Hu, W. MicroRNA-106a-3p induces apatinib resistance and activates Janus-Activated Kinase 2 (JAK2)/Signal Transducer and Activator of Transcription 3 (STAT3) by targeting the SOCS system in gastric cancer. Med. Sci. Monit. 2019, 25, 10122-10128. [CrossRef] [PubMed]

236. Zhao, X.; Li, D.; Zhao, S.T.; Zhang, Y.; Xu, A.; Hu, Y.Y.; Fang, Z. MiRNA-616 aggravates the progression of bladder cancer by regulating cell proliferation, migration and apoptosis through downregulating SOX7. Eur. Rev. Med. Pharmacol. Sci. 2019, 23, 9304-9312. [CrossRef] [PubMed] 
237. Song, Y.H.; Wang, J.; Nie, G.; Chen, Y.J.; Li, X.; Jiang, X.; Cao, W.H. MicroRNA-509-5p functions as an anti-oncogene in breast cancer via targeting SOD2. Eur. Rev. Med. Pharmacol. Sci. 2017, 21, 3617-3625. [CrossRef]

238. Siege, S.R.; MacKenzie, J.; Chaplin, G.; Jablonski, N.G.; Griffiths, L. Circulating microRNAs involved in multiple sclerosis. Mol. Biol. Rep. 2012, 39, 6219-6225. [CrossRef]

239. Magenta, A.; Cencioni, C.; Fasanaro, P.; Zaccagnini, G.; Greco, S.; Sarra-Ferraris, G.; Antonini, A.; Martelli, F.; Capogrossi, M.C. MiR-200c is upregulated by oxidative stress and induces endothelial cell apoptosis and senescence via ZEB1 inhibition. Cell Death Differ. 2011, 18, 1628-1639. [CrossRef]

240. Chen, Y.; Li, Y.; Gao, H. Long noncoding RNA CASC9 promotes the proliferation and metastasis of papillary thyroid cancer via sponging miR-488-3p. Cancer Med. 2020, 9, 1830-1841. [CrossRef]

241. Shibayama, Y.; Kubo, Y.; Nakagawa, T.; Iseki, K. MicroRNA-101-5p suppresses the expression of the ras-related protein RAP1A. Biol. Pharm. Bull. 2019, 42, 1332-1336. [CrossRef]

242. Chhabra, R. Let-7i-5p, miR-181a-2-3p and EGF/PI3K/SOX2 axis coordinate to maintain cancer stem cell population in cervical cancer. Sci. Rep. 2018, 18, 7840. [CrossRef]

243. Li, Y.; Wu, Y.; Sun, Z.; Wang, R.; Ma, D. MicroRNA-376a inhibits cell proliferation and invasion in glioblastoma multiforme by directly targeting specificity protein 1. Mol. Med. Rep. 2018, 17, 1583-1590. [CrossRef]

244. Tang, C.; Wang, X.; Ji, C.; Zheng, W.; Yu, Y.; Deng, X.; Zhou, X.; Fang, L. The Role of miR-640: A Potential Suppressor in Breast Cancer via Wnt7b/ $\beta$-catenin Signaling Pathway. Front. Oncol. 2021, 11, 1142. [CrossRef] [PubMed]

245. Liang, D.; Wu, X.; Bai, J.; Zhang, L.; Yin, C.; Zhong, W. MiR-300 inhibits invasion and metastasis of osteosarcoma cell MG63 by negatively regulating PTTG1. Nan Fang Yi Ke Da Xue Xue Bao 2021, 41, 285-291. [CrossRef] [PubMed]

246. Pan, Y.; Robertson, G.; Pedersen, L.; Lim, E.; Hernandez-Herrera, A.; Rowat, A.C.; Patil, S.L.; Chan, C.K.; Wen, Y.; Zhang, X.; et al miR-509-3p is clinically significant and strongly attenuates cellular migration and multi-cellular spheroids in ovarian cancer. Oncotarget 2016, 7, 25930. [CrossRef] [PubMed]

247. Xiao, W.; Yao, E.; Zheng, W.; Tian, F.; Tian, L. miR-337 can be a key negative regulator in melanoma. Cancer Biol. Ther. 2017, 18, 392-399. [CrossRef]

248. Gao, X.; Xu, D.; Li, S.; Wei, Z.; Li, S.; Cai, W.; Mao, N.; Jin, F.; Li, Y.; Yi, X.; et al. Pulmonary Silicosis Alters MicroRNA Expression in Rat Lung and miR-411-3p Exerts Anti-fibrotic Effects by Inhibiting MRTF-A/SRF Signaling. Mol. Ther. Nucleic Acids 2020, 20, 851-865. [CrossRef]

249. Lemecha, M.; Morino, K.; Imamura, T.; Iwasaki, H.; Ohashi, N.; Ida, S.; Sato, D.; Sekine, O.; Ugi, S.; Maegawa, H. MiR-494-3p regulates mitochondrial biogenesis and thermogenesis through PGC1- $\alpha$ signalling in beige adipocytes. Sci. Rep. 2018, 8, 15096. [CrossRef]

250. Yu, D.; Liu, X.; Han, G.; Liu, Y.; Zhao, X.; Wang, D.; Bian, X.; Gu, T.; Wen, L. The let-7 family of microRNAs suppresses immune evasion in head and neck squamous cell carcinoma by promoting PD-L1 degradation. Cell Commun. Signal. 2019, 17, 173. [CrossRef]

251. Lin, W.; Tang, Y.; Zhao, Y.; Zhao, J.; Zhang, L.; Wei, W.; Chen, J. MiR-144-3p Targets FoxO1 to Reduce Its Regulation of Adiponectin and Promote Adipogenesis. Front. Genet. 2020, 11, 603144. [CrossRef]

252. Sheedy, P.; Medarova, Z. The fundamental role of miR-10b in metastatic cancer. Am. J. Cancer Res. 2018, 8, 1674-1688.

253. Gao, C.; Wei, J.; Tang, T.; Huang, Z. Role of microRNA-33a in malignant cells (review). Oncol. Lett. 2020, 20, 2537-2556. [CrossRef]

254. Lin, Y.; Dan, H.; Lu, J. Overexpression of microRNA-136-3p Alleviates Myocardial Injury in Coronary Artery Disease via the Rho A/ROCK Signaling Pathway. Kidney Blood Press. Res. 2020, 45, 477-496. [CrossRef] [PubMed]

255. Wang, H.; Deng, Q.; Lv, Z.; Ling, Y.; Hou, X.; Chen, Z.; Dinglin, X.; Ma, S.; Li, D.; Wu, Y.; et al. N6-methyladenosine induced miR-143-3p promotes the brain metastasis of lung cancer via regulation of VASH1. Mol. Cancer 2019, 18, 181. [CrossRef] [PubMed]

256. Qiang, Z.; Jin, B.; Peng, Y.; Zhang, Y.; Wang, J.; Chen, C.; Wang, X.; Liu, F. miR-762 modulates thyroxine-induced cardiomyocyte hypertrophy by inhibiting Beclin-1. Endocrine 2019, 66, 585-595. [CrossRef] [PubMed]

257. Li, S.; Hou, X.; Wu, C.; Han, L.; Li, Q.; Wang, J.; Luo, S. MiR-645 promotes invasiveness, metastasis and tumor growth in colorectal cancer by targeting EFNA5. Biomed. Pharmacother. 2020, 125, 109889. [CrossRef]

258. Xia, L.H.; Yan, Q.H.; Sun, Q.D.; Gao, Y.P. MiR-411-5p acts as a tumor suppressor in non-small cell lung cancer through targeting PUM1. Eur. Rev. Med. Pharmacol. Sci. 2018, 22, 5546-5553. [CrossRef]

259. Chakrabarti, M.; Ray, S.K. Anti-tumor activities of luteolin and silibinin in glioblastoma cells: Overexpression of miR-7-1-3p augmented luteolin and silibinin to inhibit autophagy and induce apoptosis in glioblastoma in vivo. Apoptosis 2016, 21, 312-328. [CrossRef]

260. Liu, F.; Zhang, H.; Xie, F.; Tao, D.; Xiao, X.; Huang, C.; Wang, M.; Gu, C.; Zhang, X.; Jiang, G. Hsa_circ_0001361 promotes bladder cancer invasion and metastasis through miR-491-5p/MMP9 axis. Oncogene 2020, 39, 1696-1709. [CrossRef]

261. Yu, T.; Wang, L.N.; Li, W.; Zuo, Q.F.; Li, M.M.; Zou, Q.M.; Xiao, B. Downregulation of miR-491-5p promotes gastric cancer metastasis by regulating SNAIL and FGFR4. Cancer Sci. 2018, 109, 1393-1403. [CrossRef]

262. Li, J.; Lin, T.Y.; Chen, L.; Liu, Y.; Dian, M.J.; Hao, W.C.; Lin, X.L.; Li, X.Y.; Li, Y.L.; Lian, M.; et al. Mir-19 regulates the expression of interferon-induced genes and mhc class i genes in human cancer cells. Int. J. Med. Sci. 2020, 17, 953. [CrossRef]

263. Zhang, J.; Gao, D.; Zhang, H. Upregulation of miR-614 promotes proliferation and inhibits apoptosis in ovarian cancer by suppressing PPP2R2A expression. Mol. Med. Rep. 2018, 17, 6285-6292. [CrossRef] 
264. Gu, Y.; Cheng, Y.; Song, Y.; Zhang, Z.; Deng, M.; Wang, C.; Zheng, G.; He, Z. MicroRNA-493 suppresses tumor growth, invasion and metastasis of lung cancer by regulating E2F1. PLoS ONE 2014, 9, 102602. [CrossRef] [PubMed]

265. Cimmino, A.; Calin, G.A.; Fabbri, M.; Iorio, M.V.; Ferracin, M.; Shimizu, M.; Wojcik, S.E.; Aqeilan, R.I.; Zupo, S.; Dono, M.; et al miR-15 and miR-16 induce apoptosis by targeting BCL2. Proc. Natl. Acad. Sci. USA 2005, 102, 13944-13949. [CrossRef] [PubMed]

266. Liu, Y.; Li, J.; Li, M.; Li, F.; Shao, Y.; Wu, L. microRNA-510-5p promotes thyroid cancer cell proliferation, migration, and invasion through suppressing SNHG15. J. Cell. Biochem. 2019, 120, 11738-11744. [CrossRef] [PubMed]

267. Zhao, X.; Liu, S.; Yan, B.; Yang, J.; Chen, E. Mir-581/smad7 axis contributes to colorectal cancer metastasis: A bioinformatic and experimental validation-based study. Int. J. Mol. Sci. 2020, 21, 6499. [CrossRef]

268. Ren, K.; Yu, Y.; Wang, X.; Liu, H.; Zhao, J. MiR-340-3p-HUS1 axis suppresses proliferation and migration in lung adenocarcinoma cells. Life Sci. 2021, 274, 119330. [CrossRef]

269. Monteleone, N.J.; Lutz, C.S. miR-708-5p: A microRNA with emerging roles in cancer. Oncotarget 2017, 8, 71292-71316. [CrossRef]

270. Ramírez-Salazar, E.G.; Almeraya, E.V.; López-Perez, T.V.; Patiño, N.; Salmeron, J.; Velázquez-Cruz, R. MicroRNA-548-3p overexpression inhibits proliferation, migration and invasion in osteoblast-like cells by targeting STAT1 and MAFB. J. Biochem. 2020, 168, 203-211. [CrossRef]

271. Shi, J.; Gong, L.; Chen, L.; Luo, J.; Song, G.; Xu, J.; Lv, Z.; Tao, H.; Xia, Y.; Ye, Z. miR-618 Suppresses Metastasis in Gastric Cancer by Downregulating the Expression of TGF- $\beta 2$. Anat. Rec. 2019, 302, 931-940. [CrossRef]

272. Sun, Y.; Zhao, J.; Yin, X.; Yuan, X.; Guo, J.; Bi, J. miR-297 acts as an oncogene by targeting GPC5 in lung adenocarcinoma. Cell Prolif. 2016, 49, 636-643. [CrossRef]

273. Yao, Y.; Jia, H.; Wang, G.; Ma, Y.; Sun, W.; Li, P. MiR-297 protects human umbilical vein endothelial cells against LPS-induced inflammatory response and apoptosis. Cell. Physiol. Biochem. 2019, 52, 696-707. [CrossRef]

274. Liu, Z.; Lu, X.; Wen, L.; You, C.; Jin, X.; Liu, J. Hsa_circ_0014879 regulates the radiosensitivity of esophageal squamous cell carcinoma through miR-519-3p/CDC25A axis. Anticancer. Drugs 2021, 33, e349-e361. [CrossRef] [PubMed]

275. Zhang, X.L.; An, B.F.; Zhang, G.C. MiR-27 alleviates myocardial cell damage induced by hypoxia/reoxygenation via targeting TGFBR1 and inhibiting NF-kB pathway. Kaohsiung J. Med. Sci. 2019, 35, 607-614. [CrossRef] [PubMed]

276. Qian, F.H.; Deng, X.; Zhuang, Q.X.; Wei, B.; Zheng, D.D. MiR-625-5p suppresses inflammatory responses by targeting AKT2 in human bronchial epithelial cells. Mol. Med. Rep. 2019, 19, 1951-1957. [CrossRef] [PubMed]

277. Yoshida, K.; Yokoi, A.; Yamamoto, Y.; Kajiyama, H. ChrXq27.3 miRNA cluster functions in cancer development. J. Exp. Clin. Cancer Res. 2021, 40, 1-11. [CrossRef] [PubMed]

278. Lv, P.; Luo, Y.F.; Zhou, W.Y.; Liu, B.; Zhou, Z.; Shi, Y.Z.; Huang, R.; Peng, C.; He, Z.L.; Wang, J.; et al. miR-373 inhibits autophagy and further promotes apoptosis of cholangiocarcinoma cells by targeting ULK1. Kaohsiung J. Med. Sci. 2020, 36, 429-440. [CrossRef] [PubMed]

279. Chen, T.; Qin, S.; Gu, Y.; Pan, H.; Bian, D. Long non-coding RNA NORAD promotes the occurrence and development of non-small cell lung cancer by adsorbing MiR-656-3p. Mol. Genet. Genomic Med. 2019, 7, e757. [CrossRef] [PubMed]

280. He, W.; Cheng, Y. Inhibition of miR-20 promotes proliferation and autophagy in articular chondrocytes by PI3K/AKT/mTOR signaling pathway. Biomed. Pharmacother. 2018, 97, 607-615. [CrossRef]

281. Zhang, Y.; Dai, J.; Tang, J.; Zhou, L.; Zhou, M. MicroRNA-649 promotes HSV-1 replication by directly targeting MALT1. J. Med. Virol. 2017, 89, 1069-1079. [CrossRef]

282. Pepe, F.; Visone, R.; Veronese, A. The glucose-regulated MiR-483-3p influences key signaling pathways in cancer. Cancers 2018, 10, 181. [CrossRef]

283. Lu, J.; Zhou, L.; Wu, B.; Duan, Y.; Sun, Y.; Gu, L.; Xu, D.; Du, C. MiR-501-3p functions as a tumor suppressor in non-small cell lung cancer by downregulating RAP1A. Exp. Cell Res. 2020, 387, 111752. [CrossRef]

284. Zhang, D.; Yang, N. MiR-335-5p inhibits cell proliferation, migration and invasion in colorectal cancer through downregulating LDHB. J. Buon 2019, 24, 1128-1136. [PubMed]

285. Gracia-Cazaña, T.; González, S.; Parrado, C.; Juarranz, Á.; Gilaberte, Y. Influence of the Exposome on Skin Cancer. Actas Dermosifiliogr. 2020, 111, 460-470. [CrossRef] [PubMed]

286. Pecorelli, A.; Cordone, V.; Messano, N.; Zhang, C.; Falone, S.; Amicarelli, F.; Hayek, J.; Valacchi, G. Altered inflammasome machinery as a key player in the perpetuation of Rett syndrome oxinflammation. Redox Biol. 2020, 28, 101334. [CrossRef] [PubMed]

287. Valacchi, G.; Sticozzi, C.; Pecorelli, A.; Cervellati, F.; Cervellati, C.; Maioli, E. Cutaneous responses to environmental stressors Ann. N. Y. Acad. Sci. 2012, 1271, 75-81. [CrossRef] [PubMed]

288. Valacchi, G.; Virgili, F.; Cervellati, C.; Pecorelli, A. OxInflammation: From subclinical condition to pathological biomarker. Front. Physiol. 2018, 9, 858. [CrossRef] [PubMed]

289. Vierkötter, A.; Schikowski, T.; Ranft, U.; Sugiri, D.; Matsui, M.; Krämer, U.; Krutmann, J. Airborne particle exposure and extrinsic skin aging. J. Investig. Dermatol. 2010, 130, 2719-2726. [CrossRef]

290. Magnani, N.D.; Muresan, X.M.; Belmonte, G.; Cervellati, F.; Sticozzi, C.; Pecorelli, A.; Miracco, C.; Marchini, T.; Evelson, P.; Valacchi, G. Skin damage mechanisms related to airborne particulate matter exposure. Toxicol. Sci. 2016, 149, 227-236. [CrossRef] [PubMed] 
291. Furukawa, J.Y.; Martinez, R.M.; Morocho-Jácome, A.L.; Castillo-Gómez, T.S.; Pereda-Contreras, V.J.; Rosado, C.; Velasco, M.V.R.; Baby, A.R. Skin impacts from exposure to ultraviolet, visible, infrared, and artificial lights-A review. J. Cosmet. Laser Ther. 2021, 23, 1-7. [CrossRef]

292. Pattison, D.I.; Davies, M.J. Actions of ultraviolet light on cellular structures. EXS 2006, 96, 131-157. [CrossRef]

293. Svobodova, A.; Walterova, D.; Vostalova, J. Ultraviolet light induced alteration to the skin. Biomed. Pap. Med. Fac. Univ. Palacky. Olomouc. Czech. Repub. 2006, 150, 25-38. [CrossRef]

294. Fritsche, K. Important differences exist in the dose-response relationship between diet and immune cell fatty acids in humans and rodents. Lipids 2007, 42, 961-979. [CrossRef] [PubMed]

295. Xu, J.; Li, C.X.; Li, Y.S.; Lv, J.Y.; Ma, Y.; Shao, T.T.; Xu, L.D.; Wang, Y.Y.; Du, L.; Zhang, Y.P.; et al. MiRNA-miRNA synergistic network: Construction via co-regulating functional modules and disease miRNA topological features. Nucleic Acids Res. 2011, 39, 825-836. [CrossRef] [PubMed]

296. Fry, R.C.; Rager, J.E.; Bauer, R.; Sebastian, E.; Peden, D.B.; Jaspers, I.; Alexis, N.E. Air toxics and epigenetic effects: Ozone altered microRNAs in the sputum of human subjects. Am. J. Physiol. Lung Cell. Mol. Physiol. 2014, 306, L1129-L1137. [CrossRef] [PubMed]

297. Abdel-Shafy, H.I.; El-Khateeb, M.A.; Mansour, M.S.M. Treatment of leather industrial wastewater via combined advanced oxidation and membrane filtration. Water Sci. Technol. 2016, 74, 586-594. [CrossRef] [PubMed]

298. Izzotti, A.; Calin, G.A.; Arrigo, P.; Steele, V.E.; Croce, C.M.; De Flora, S. Downregulation of microRNA expression in the lungs of rats exposed to cigarette smoke. FASEB J. 2009, 23, 806-812. [CrossRef] [PubMed]

299. Izzotti, A.; Pulliero, A. The effects of environmental chemical carcinogens on the microRNA machinery. Int. J. Hyg. Environ. Health 2014, 217, 601-627. [CrossRef] [PubMed]

300. Huang, Y.; Unger, N.; Harper, K.; Heyes, C. Global Climate and Human Health Effects of the Gasoline and Diesel Vehicle Fleets. GeoHealth 2020, 4, e2019GH000240. [CrossRef]

301. Izzotti, A.; Pulliero, A. Molecular damage and lung tumors in cigarette smoke-exposed mice. Ann. N. Y. Acad. Sci. 2015, 1340, 75-83. [CrossRef]

302. Meek, M.D. Ah receptor and estrogen receptor-dependent modulation of gene expression by extracts of diesel exhaust particles. Environ. Res. 1998, 79, 114-121. [CrossRef]

303. Hoskin, R.; Pambianchi, E.; Pecorelli, A.; Grace, M.; Therrien, J.P.; Valacchi, G.; Lila, M.A. Novel spray dried algae-rosemary particles attenuate pollution-induced skin damage. Molecules 2021, 26, 3781. [CrossRef]

304. Izzotti, A.; Calin, G.A.; Steele, V.E.; Croce, C.M.; De Flora, S. Relationships of microRNA expression in mouse lung with age and exposure to cigarette smoke and light. FASEB J. 2009, 23, 3243-3250. [CrossRef] [PubMed] 